\title{
Sensitivity of tropospheric loads and lifetimes of short lived pollutants to fire emissions
}

\author{
N. Daskalakis ${ }^{1,2}$, S. Myriokefalitakis ${ }^{1}$, and M. Kanakidou ${ }^{1}$ \\ ${ }^{1}$ Environmental Chemical Processes Laboratory, Department of Chemistry, University of Crete, \\ Heraklion, Crete, Greece \\ ${ }^{2}$ Institute of Chemical Engineering Sciences (ICE-HT), FORTH, Patra, Greece \\ Correspondence to: M. Kanakidou (mariak@chemistry.uoc.gr)
}

Received: 15 August 2014 - Published in Atmos. Chem. Phys. Discuss.: 3 September 2014

Revised: 24 February 2015 - Accepted: 25 February 2015 - Published: 31 March 2015

\begin{abstract}
The capability of global chemistry and transport models (CTMs) to simulate atmospheric composition and its spatial and temporal changes highly relies on the input data used by the models, in particular the emission inventories. Biomass burning emissions show large spatial, diurnal, seasonal and year-to-year variability. In the present study, we applied a global 3-D CTM to evaluate uncertainties in the computed atmospheric composition associated with the use of different biomass burning emissions and identify areas where observational data can help to reduce these uncertainties. We find the emission inventory choice to lead to regional differences in the calculated load of aerosols up to a factor of 4 . Assumptions on the injection height of the biomass burning emissions are found to produce regionally up to $30 \%$ differences in the calculated tropospheric lifetimes of pollutants. Computed changes in lifetimes point to a strong chemical feedback mechanism between emissions from biomass burning and isoprene emissions from vegetation that are linked via $\mathrm{NO}_{\mathrm{x}}$-driven oxidant chemistry, $\mathrm{NO}_{\mathrm{x}}$-dependent changes in isoprene oxidation products, aerosol emissions and atmospheric transport. These interactions reduce isoprene load in the presence of biomass burning emissions by $15 \%$, calculated for the same amount of isoprene emitted into the troposphere. Thus, isoprene load and lifetime are inversely related to the quantities of pollutants emitted by biomass burning. These interactions are shown to be able to increase the global annual secondary aerosol yield from isoprene emissions, defined as the ratio of tropospheric loads of secondary aerosol from isoprene oxidation to isoprene emissions, by up to $18 \%$.
\end{abstract}

\section{Introduction}

Atmospheric composition is affected by emissions of reactive gases and aerosols to the atmosphere by several natural (e.g., soils, vegetation, oceans, volcanoes, wildfires) and anthropogenic sources (e.g., industrial and residential activities, transport, and shipping). Among these sources biomass burning plays a central role for atmospheric chemistry via changes in the atmospheric composition but also impacting on the ecosystem functioning through atmospheric deposition of nutrients and the life cycle of vegetation (Keywood et al., 2013). Biomass burning is positioned between the natural (wildfires) and human-induced (intentional burning) sources of atmospheric pollutants since a fraction of open fires is induced by humans for agricultural and city expansion purposes (Levine et al., 1995) or for protection against fire itself (Mutch, 1994). Biomass burning is an important source of trace constituents to the atmosphere including radiatively and chemically reactive gases and aerosols (Andreae and Merlet, 2001; Akagi et al., 2011). It is the largest source of primary carbonaceous aerosols (Bond et al., 2004) and the second largest source of volatile organic compounds (VOCs) in the atmosphere after the emissions from vegetation (Guenther et al., 2012) and of carbon monoxide (CO) after anthropogenic emissions (Kanakidou and Crutzen, 1999; Pfister et al., 2005).

Emissions from biomass burning and their transformation in the atmosphere affect air quality (Lelieveld et al., 2004), interact with radiation (Reid et al., 2005) and the atmospheric water cycle and thus affect climate (Rosenfeld, 1999). In turn, climate change is seen to have impact on wildfire occur- 
rence and intensity. For instance, the exceptionally intensive 1997/1998 Indonesia fires have been attributed to the combined strength of the El Niño and the Indian Ocean Dipole (Field et al., 2009).

Significant changes in the trends of atmospheric concentrations of $\mathrm{CH}_{4}$ and $\mathrm{CO}$ have been attributed to the changes in the biomass burning emissions (Simmonds et al., 2005). Most of these emissions occur in the tropics that are subject to intensive photochemistry in the presence of high humidity conditions and significant convective activities (Chatfield and Delany, 1990; Crutzen, 1994). During summer, in the high latitudes boreal forest fires contribute about $12 \%$ to the global biomass burning emissions (Lavoué et al., 2000) and can be so intensive and convective that their emissions reach the high troposphere and low stratosphere (Fromm et al., 2000).

Tropical photochemistry controls the lifetime of most atmospheric pollutants (Crutzen, 1994; Keywood et al., 2013) including reactive greenhouse gases like methane $\left(\mathrm{CH}_{4}\right)$ and ozone $\left(\mathrm{O}_{3}\right)$ and, thus, their persistence in the atmosphere to impact on radiation and climate. Up to about $25 \%$ of the net global photochemical production of tropospheric ozone has been attributed to biomass burning emissions and chemistry in the atmosphere (Crutzen and Andreae, 1990; Jaffe and Wigder, 2012). Long range transport of biomass burning aerosols has been seen to happen fast within 1 or 2 weeks both downwind tropical (Edwards et al., 2006; Dirksen et al., 2009) and high-latitude sources (Jaffe et al., 2004). Thus, this source is affecting atmospheric pollutant levels in remote environments. For instance, chemical ageing of fire plumes has been identified as a contributor to the high ozone over the Atlantic ocean (Lelieveld et al., 2004). Therefore, it is important to simulate the impact of biomass burning emissions on tropospheric composition and pollutant lifetimes and to evaluate the uncertainties in such simulations.

Several biomass burning emission inventories have been constructed based on burned area, active fire detections, and plant productivity from satellite observations (van der Werf et al., 2010) or on assimilated fire radiative power derived from satellite observations (Kaiser et al., 2012) and experimentally determined pollutant emission factors (Andreae and Merlet, 2001) and assumptions on the state of burning of the biomass (smoldering or flaming, van der Werf et al., 2006). All these factors introduce uncertainties in the emissions (Granier et al., 2011; Wiedinmyer et al., 2011). In particular, the size of small fires can be overestimated and the number of fires can be underestimated when seen by satellites (Wiedinmyer et al., 2011). The injection height of fire emissions (Dentener et al., 2006; Freitas et al., 2007; Sofiev et al., 2012) is an additional cause of discrepancies in the model estimates of the impact of these fires on tropospheric composition. The height distribution proposed by Dentener et al. (2006) (used in this work) is based on wildfire location and type, where the distribution described in Sofiev et al. (2012) is based on the fire characteristics (fire intensity, temperature of plume, type of source) as well as the meteorological conditions (atmospheric boundary layer height, free troposphere). These two approaches show similarities in emission heights over North America and Oceania but over Eurasia, Australia and South America the two methods show significant differences (Sofiev et al., 2013). A plume-height climatology over North America has been also derived by analysis of 5-year satellite observations by MISR (Multiangle Imaging SpectroRadiometer; Val Martin et al., 2010) which compared to the Dentener et al. (2006) vertical distribution of fires there (2000-6000 m) shows lower mean injection heights $(500-1500 \mathrm{~m})$ for boreal fires but is in agreement for temperate and tropical fires. Plume-rise models evaluated against that climatology have been shown to underestimate the observed plume heights (Val Martin et al., 2012). Guan et al. (2008) using the NCAR CAM3.1 model found that the calculated $\mathrm{CO}$ concentrations downwind of biomass burning emission areas can increase by up to $150 \mathrm{ppb}$ depending on the assumptions in the injection height of the emissions. Boreal forest fire emissions occurring high in the troposphere have been detected by Colarco et al. (2004) to be transported from Canada to Washington DC in the USA where they have been mixed with boundary layer air. Long-range transport of biomass burning pollutants has been followed by lidar and satellite observations and the simulations have been shown to be sensitive to the injection height of the emissions as well as to the entrainment of air into the boundary layer over USA. Note that boreal fire plumes can reach the upper troposphere where their impact is different from that in the boundary layer due to the non-linearities in the atmospheric chemistry (Chatfield and Delany, 1990) and the different photochemical conditions there. The Leung et al. (2007) global modeling study of the impact of boreal fire emissions on air pollutants levels found a much larger enhancement in ozone when about half the emissions were released above the boundary layer than when all emissions were occurring in the boundary layer. They attributed these differences to the role of peroxyacetyl nitrate (PAN) as carrier of $\mathrm{NO}_{\mathrm{x}}$ downwind of burning areas. Jaffe et al. (2004) found that the intensive Siberian fires in 2003 enhanced the background ozone over the Pacific northwest of the USA, resulting in exceedance of the ozone air quality standard. Hodzic et al. (2006), studying AOT (aerosol optical thickness) over Europe during the 2003 Portuguese fires, identified high altitude transport of smoke particles from Portugal to the Netherlands, which has been both observed by POLDER-2 and simulated by the CHIMERE model. Williams et al. (2012) simulated the African fires in 2005 using the TM4 model and three different biomass burning emission inventories, two global and one regional. They calculated differences in the ozone global burden resulting from the use of different biomass burning inventories that range between +1.7 and $+4.6 \%$ compared to the simulation using the GFEDv3 (Global Fire Emission Database v3.1) biomass burning emission inventory. 
The present study aims to evaluate uncertainties in model estimates of biomass burning impacts on atmospheric composition that are associated with the use of different emission inventories in the same model. The study also aims to identify locations where additional observations can provide constrains for biomass burning emission estimates. For this purpose, a global 3-D chemistry and transport model (CTM) is applied to evaluate uncertainties in the atmospheric composition and major pollutant lifetimes computed using recently updated and commonly used biomass burning emissions. Based on the computed model sensitivity to biomass burning emissions, we also identify areas where observational data can help to reduce these uncertainties.

\section{Model description}

The model used for this study is the global 3-D CTM TM4ECPL (Kanakidou et al., 2012). The model accounts for gas and multiphase chemistry to describe tropospheric ozone chemistry and all major aerosol components (primary and secondary). It contains explicit chemistry of $\mathrm{C}_{1}-\mathrm{C}_{5}$ volatile organic compounds (VOCs) and a highly simplified representation of $a$-pinene and $\beta$-pinene chemistry. The model calculates secondary organic aerosol (SOA) formation by VOC oxidation and subsequent gas-to-particle partitioning of semivolatile products (Tsigaridis and Kanakidou, 2007), as updated by Myriokefalitakis et al. (2010). Chemical aging of organic aerosol (OA) is also taken into account. For primary organic aerosol (POA) and black carbon (BC) chemical ageing is considered to occur by oxidation of organic material that coats the particles and is driven by $\mathrm{O}_{3}$ (Tsigaridis and Kanakidou, 2003); while for SOA chemical ageing to non-volatile SOA (Tsigaridis and Kanakidou, 2003) is considered to occur by reaction with $\mathrm{OH}$ at the rate of $4.10^{-12} \mathrm{molec}^{-1} \mathrm{~cm}^{3} \mathrm{~s}^{-1}$, very close to that of the $\mathrm{H}$-abstraction reaction of pinonic acid with $\mathrm{OH}$ (Praplan et al., 2012). BC emissions are by $20 \%$ soluble while terrestrial POA emissions are by $50 \%$ soluble. For both BC and POA the insoluble fraction is converted to soluble during aging. Multiphase chemical production of SOA is parameterized as described in Myriokefalitakis et al. (2011). Gas-toparticle partitioning of inorganic components is solved using the ISORROPIA II aerosol thermodynamic model that also calculates the aerosol water (Nenes et al., 1998; Fountoukis and Nenes, 2007). For this study the TM4-ECPL model uses a $3^{\circ} \times 2^{\circ}$ longitude-latitude grid and 34 hybrid levels of up to $0.1 \mathrm{hPa}$ (with the first four model vertical layers between surface and $900 \mathrm{hPa}$ ) and is driven by the European Centre for Medium-range Weather Forecasts (ECMWF) ERA-Interim meteorological data (Dee et al., 2011) for the year 2008 for all the sensitivity simulations.

\subsection{Natural emissions}

Isoprene, terpenes and biogenic volatile organic compound (BVOC) emissions in the TM4-ECPL model are taken from the MEGAN-MACC (Model of Emissions of Gases and Aerosols from Nature-Monitoring Atmospheric Composition and Climate) inventory (Sindelarova et al., 2014) for the year 2008, which is a product of the MEGANv2.1 model (Guenther et al., 2012). Dust emissions are from AeroCom (Aerosol Comparisons between Observations and Models; (Dentener et al., 2006) calculated for the year 2008 by E. Vignati, personal communication, 2011). Marine emissions of sea-salt aerosols and organic gases and aerosols are calculated online driven by meteorology and sea water productivity as described by Myriokefalitakis et al. (2010) and Vignati et al. (2010).

\subsection{Anthropogenic emissions}

Anthropogenic emissions used for this experiment are the ECLIPSE (Evaluating the CLimate and Air Quality ImPacts of Short-livEd Pollutants) version 4.0 emissions (Klimont et al., 2013), available in $0.5^{\circ} \times 0.5^{\circ}$ spatial resolution. The ECLIPSE anthropogenic inventory was initially provided as sectoral including the agricultural waste burning sector (AWB). Since AWB is either included in the anthropogenic emissions or in the biomass burning emissions, caution was taken to avoid double counting of the emissions. For this, the AWB emissions (Table 3) are considered separately for the simulations that have been performed for this study (Table 4). The AWB in the ECLIPSE database amounts to $4.5 \%$ of the total anthropogenic pollutant emissions (approximately $34.5 \mathrm{Tg} \mathrm{a}^{-1}$ ) for the year 2008 (see Table 1 for more information). Anthropogenic emissions of all basic pollutants are used: $\mathrm{CO}$, nitrogen oxides $\left(\mathrm{NO}_{\mathrm{x}}\right)$, black carbon aerosol (BC), particulate organic carbon (OC), sulfur dioxide and sulfates $\left(\mathrm{SO}_{\mathrm{x}}\right)$ as well as speciated non-methane volatile organic compounds (NMVOCs; for a list of the NMVOCs used in the model see Supplement S1).

\subsection{Biomass burning emissions}

For the present study a number of sensitivity simulations have been performed (Table 4) using different biomass burning emissions (Table 2) and AWB emissions (Table 3), all for the year 2008. For the base simulation (S0.0), the biomass burning emissions from the GFEDv3 (van der Werf et al., 2010) are used, excluding the AWB sector (Table 3), hereafter called GFEDv3-ECLIPSE biomass burning emissions (S0.X), while AWB emissions are taken from the ECLIPSE anthropogenic emissions developed in the framework of the ECLIPSE project. Additional simulations have been performed (Table 4) using both biomass burning and AWB emissions from the GFEDv3 (van der Werf et al., 2010) (S1.X), as well as AWB from ECLIPSE and biomass burn- 
Table 1. Anthropogenic emissions $\left(\mathrm{Tg} \mathrm{a}^{-1}\right)$ used in this study and fraction of emissions that corresponds to the AWB sector included in the ECLIPSE anthropogenic emissions inventory. Both absolute quantities and percentage of the total anthropogenic emissions from Klimont et al. (2013) are presented.

\begin{tabular}{lrrrrrr}
\hline & $\mathrm{BC}$ & $\mathrm{CO}$ & $\mathrm{NO}_{\mathrm{x}}$ & $\mathrm{OC}$ & $\mathrm{SO}_{\mathrm{x}}$ & $\mathrm{NMVOC}$ \\
\hline ECLIPSE (with AWB) & 5.38 & 527.1 & 43.97 & 11.56 & 45.95 & 140.47 \\
AWB on ECLIPSE & 0.333 & 27.46 & 0.296 & 1.281 & 0.173 & 4.255 \\
$\%$ contribution of AWB to total anthropogenic & 6.19 & 5.21 & 0.67 & 11.08 & 0.38 & 3.03 \\
\hline
\end{tabular}

Table 2. Total annual amounts of pollutants emitted by wildfires according to the different inventories used, for 2008 (in $\mathrm{Tg} \mathrm{a}^{-1}$ ). $\mathrm{NO}_{\mathrm{x}}$ is reported as NO. (*)GFEDv3.1 without the AWB is here called GFEDv3.1-ECLIPSE

\begin{tabular}{lrrrrrrrrr}
\hline & $\mathrm{BC}$ & $\mathrm{CO}$ & $\mathrm{NO}_{\mathrm{x}}$ & $\mathrm{OC}$ & $\mathrm{SO}_{2}$ & $\mathrm{NMVOC}$ & $\mathrm{NH}_{3}$ & $\begin{array}{r}\text { Spatial } \\
\text { resolution }\end{array}$ & $\begin{array}{c}\text { Temporal } \\
\text { resolution }\end{array}$ \\
\hline GFEDv3.1-ECLIPSE* & 1.695 & 264.205 & 3.751 & 15.197 & 0.940 & 44.414 & 3.320 & $0.5^{\circ} \times 0.5^{\circ}$ & Monthly \\
FINN & 1.939 & 338.576 & 5.998 & 20.202 & 1.102 & 63.476 & 5.410 & $1^{\circ} \times 1^{\circ}$ & $\mathrm{Monthly}^{\circ}$ \\
ACCMIP & 2.620 & 460.419 & 5.479 & 23.309 & 1.929 & 80.869 & 9.203 & $0.5^{\circ} \times 0.5^{\circ}$ & Monthly $^{2}$ \\
\hline
\end{tabular}

Table 3. Agricultural waste burning sector as provided for different emission inventories (in $\mathrm{Tg} \mathrm{a}^{-1}$ ) for the year 2008. $\mathrm{NO}_{\mathrm{X}}$ is reported as NO.

\begin{tabular}{lrrrrrr}
\hline & $\mathrm{BC}$ & $\mathrm{CO}$ & $\mathrm{NO}_{\mathrm{x}}$ & $\mathrm{OC}$ & $\mathrm{SO}_{\mathrm{x}}$ & $\mathrm{NMVOC}$ \\
\hline ECLIPSE & 0.333 & 27.46 & 0.296 & 1.281 & 0.173 & 4.255 \\
GFEDv3.1 & 0.064 & 12.57 & 0.143 & 0.497 & 0.027 & 1.296 \\
ACCMIP & 0.162 & 21.22 & 0.444 & 0.775 & 0.220 & 2.857 \\
\hline
\end{tabular}

ing emissions from the Atmospheric Chemistry and Climate Model Intercomparison Project's (ACCMIP; Lamarque et al. 2013, http://eccad.sedoo.fr) (S2.X), from the Fire INventory from NCAR (FINN; Wiedinmyer et al. 2011; http: //bai.acd.ucar.edu/Data/fire/) (S3.X) and, finally, from a simulation where no biomass burning emissions were taken into account (S4.0). Since the injection height of these emissions contributes to the uncertainty of the model results, biomass burning emissions are considered in the model either to be injected at heights following Dentener et al. (2006) or to be emitted solely in the lowest model layer (see list of simulations in Table 4). The temporal variability of theses biomass burning inventories per emitted species for 2008 is shown in Table 6. Figure 1 depicts the differences between the inventories in their seasonality and amplitude (also annual totals in Table 2); while Fig. S2 in the Supplement shows the spatial difference in the annual $\mathrm{BC}$ emissions between the inventories. The ACCMIP inventory shows the largest magnitude in the temporal variation of these emissions. All inventories show a July-September primary maximum while they differ in the secondary maximum between January and April. The AWB emissions that are not included in the GFEDv3ECLIPSE biomass burning inventory significantly contribute to $\mathrm{NMVOC}$ and $\mathrm{NH}_{3}$ emissions during spring and summer.

\section{Experiment setup}

The impact of the use of different biomass burning emission inventories on the calculated tropospheric loads and lifetimes of the main pollutants and the sensitivity of the model results to the wildfire emissions have been evaluated based on nine different simulations. For all simulations the model setup was exactly the same, except for the biomass burning emissions inventory used and its vertical distribution application. A summary of the simulations here performed is provided in Table 4. The GFEDv3-ECLIPSE inventory and height distribution for biomass burning emissions have been used as the base case scenario (S0.0). All scenarios named SX.0 assume the same fractional height distribution of the emissions according to Dentener et al. (2006) where all the scenarios named SX.1 assume all open biomass burning emissions to occur at the surface. For scenario S4.0, open biomass burning emissions are set to zero. Note that we have chosen to account for monthly mean emissions since not all inventories have higher temporal resolution. This is the reason we have also chosen to validate the model results by comparing them to monthly mean observations.

\section{Results}

To evaluate the ability of the model to reproduce the observations, the computed concentrations are compared with measurements. The differences in the fields computed by the various emission inventories provide a measure for the robustness of the model results with regard to the biomass burning impacts. Comparison of the simulated tropospheric concentrations of pollutants between the various scenarios reveals the spatial and temporal differences due to the different inventories and could indicate which inventory is performing the best. Ultimately, these differences will point to 
Table 4. Summary of simulations performed for this work.

\begin{tabular}{lllll}
\hline Height & inventory & Varying & Surface & AWB \\
\hline S0.0 & GFEDv3-ECLIPSE & $\mathrm{X}$ & & ECLIPSE \\
S0.1 & & & $\mathrm{X}$ & \\
S1.0 & GFEDv3.1 & $\mathrm{X}$ & & GFEDv3.1 \\
S1.1 & & & $\mathrm{X}$ & \\
S2.0 & ACCMIP & $\mathrm{X}$ & & ECLIPSE \\
S2.1 & & & $\mathrm{X}$ & \\
S3.0 & FINN & $\mathrm{X}$ & & ECLIPSE \\
S3.1 & & & $\mathrm{X}$ & \\
S4.0 & zero & & & ECLIPSE \\
\hline
\end{tabular}

areas where additional observations can contribute to reducing uncertainties of the emission inventories as will be further discussed. Finally, tropospheric lifetimes are calculated to provide information on how the location and strength of the emissions affect the persistence of the pollutants in the atmosphere.

\subsection{Comparison with ground measurements}

Surface observations of ozone from the European Monitoring and Evaluation Programme (EMEP) monitoring network (Europe), ozone and CO observations from the World Data Centre for Greenhouse Gases (WDCGG) database (Global) and particulate OC observations from the AeroCom phase II database (Global) (Tsigaridis et al., 2014) have been used for the model evaluation. The locations of measurements are shown in Fig. S1. While all available data have been used for model evaluation, only comparisons at stations that have been selected to make evident differences between the simulations using different biomass burning emission inventories are shown for OC (Fig. 2), $\mathrm{CO}$ (Fig. 3) and $\mathrm{O}_{3}$ (Fig. 4). Concentration fields of primary pollutants emitted by biomass burning are more strongly affected by the different emission inventories and injection heights. Thus, OC-computed concentrations (Fig. 2) and BC concentrations (not shown) present the largest diversity between simulations, followed by $\mathrm{CO}$ (Fig. 3) which is emitted by fires but has also secondary sources.

The simulated OC for the various scenarios and their differences from the observations in the tropics, the subtropics and high latitudes at locations affected by biomass burning emissions are shown in Fig. 2. Due to limited observational data from the tropics where most of the biomass burning occurs, for the following comparisons all available data have been used independently of the year. Modeled differences for OC due to emission inventory choice can exceed a factor of 3 at Alta Floresta (Fig. 2c) and 8 at Rondonia (Fig. 2d) during the biomass burning months. Using the ACCMIP inventory, the largest OC levels are computed at the tropical station of Alta Floresta in August and September, whereas the GFEDv3-ECLIPSE and GFEDv3 inventories include large amounts of OC injections at the subtropical stations of Cali- fornia in June, July and August (Fig. 2b, g). Different emission inventories significantly affect the model performance over and downwind of locations where wildfires occur. Unfortunately, current observational sites do not provide sufficient constraint for the emission databases evaluation.

The Tsigaridis et al. (2014) OC global model intercomparison exercise has indicated that among the 31 models contributing to that study, some models emit all biomass burning aerosols at the surface, while most models distribute them to a number of layers above the surface, typically within the boundary layer. Most models use GFEDv3 and ACCMIP inventories and all models appear to have similar seasonality in primary $\mathrm{OC}$ emissions with increased emissions during Northern Hemisphere summer due to the enhanced contribution of Northern Hemisphere biomass burning emissions from temperate and boreal forests to the total OC fluxes. Kaiser et al. (2012) found systematic model underestimations of smoke aerosol optical depth (AOD) observed by MODIS that can be as high as a factor of 3 on the global scale when emissions from bottom-up inventories like GFED are used. Petrenko et al. (2012) have demonstrated that such underestimations strongly vary by region.

Similar to $\mathrm{OC}$, results are obtained for $\mathrm{CO}$, as seen in Fig. 3, where during the biomass burning season different quantities of $\mathrm{CO}$ are calculated depending on the inventory used. At Yonagunijima (Fig. 3a), CO concentration differences computed using the different inventories maximize in spring and models underestimate measurements by $25 \%$. Such differences between inventories are large at the East Trout Lake station in Canada, where in June and July model results differ by up to $150 \mathrm{ppb}$ (a factor of 2.5 ). These results reflect the extremely high emissions in the GFEDv3ECLIPSE and GFEDv3 inventories for this region, which are not seen in the measurements (Fig. 3b). The assumption that all emissions occur near the surface leads to about $60 \%$ higher $\mathrm{CO}$ surface concentrations than when emissions are distributed vertically. At the areas where biomass burning occurs, and downwind of them, these emissions contribute between 10 and $75 \%$ to the total CO levels during the burning season.

Comparisons of $\mathrm{O}_{3}$ simulations with surface measurements (Fig. 4) show a noticeable difference between the simulation that neglects wildfire emissions (S4.0) and all other simulations at stations like Mt. Kenya (Fig. 4f), La Quiaca Observatory (Fig. 4g) and Hok Tsui (Fig. 4d), which are located in the vicinity or outflow of tropical biomass burning. These are areas where $\mathrm{O}_{3}$ levels are the most sensitive to the different biomass burning emission scenarios. For instance, at La Quiaca Observatory (Fig. 4g), differences as high as $10 \mathrm{ppb}$ of $\mathrm{O}_{3}$ (i.e., $\sim 25 \%$ ) are computed for October when using the different emission scenarios. The FINN inventory results in the highest computed $\mathrm{O}_{3}$ levels, while omitting biomass burning reduces $\mathrm{O}_{3}$ levels by $\sim 35 \%$. However, very small sensitivity is seen between the scenarios with wildfire emissions for the other locations in 

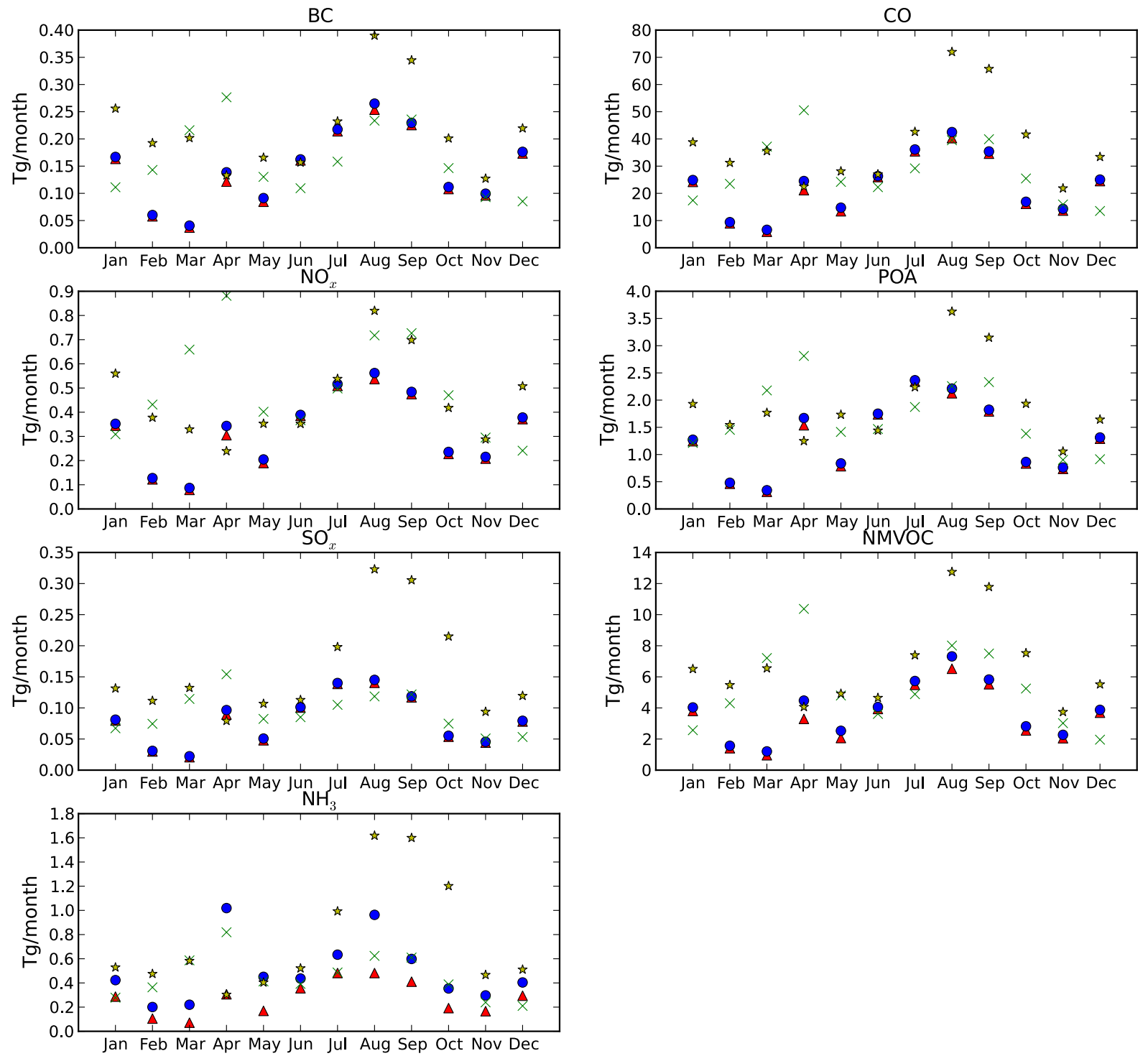

\section{$\Delta \triangle$ ECLIPSE $\bullet \bullet$ GFEDv3 $\times \times$ FINN *}

Figure 1. Monthly variation and differences of biomass burning emission inventories for the year 2008 for all species used in the model. For simplicity, NMVOCs are summed. $\mathrm{NO}_{\mathrm{x}}$ are presented in $\mathrm{NO}, \mathrm{SO}_{\mathrm{x}}$ in $\mathrm{SO}_{2}$ and $\mathrm{NMVOCs}$ in total mass.

Table 5. Total annual mean tropospheric load of pollutants for all simulations (in $\mathrm{Tg} \mathrm{a}^{-1}$ ).

\begin{tabular}{lrrrrrrrrr}
\hline & S0.0 & S0.1 & S1.0 & S1.1 & S2.0 & S2.1 & S3.0 & S3.1 & S4.0 \\
\hline $\mathrm{CO}$ & 319.12 & 318.37 & 317.26 & 316.20 & 341.47 & 339.63 & 331.58 & 330.37 & 283.88 \\
$\mathrm{O}_{3}$ & 416.17 & 415.52 & 415.35 & 414.82 & 422.17 & 421.29 & 423.04 & 422.03 & 405.25 \\
$\mathrm{NO}_{\mathbf{X}}$ & 1.299 & 1.293 & 1.286 & 1.282 & 1.330 & 1.323 & 1.390 & 1.378 & 1.200 \\
$\mathrm{SO}_{4}^{2-}$ & 1.914 & 1.908 & 1.913 & 1.906 & 1.933 & 1.923 & 1.911 & 1.905 & 1.868 \\
$\mathrm{HNO}_{3}$ & 2.196 & 2.188 & 2.181 & 2.181 & 2.235 & 2.228 & 2.229 & 2.219 & 2.048 \\
$\mathrm{NH}_{4}^{+}$ & 0.498 & 0.487 & 0.514 & 0.496 & 0.516 & 0.496 & 0.507 & 0.492 & 0.460 \\
Isoprene & 0.266 & 0.267 & 0.267 & 0.268 & 0.247 & 0.248 & 0.253 & 0.254 & 0.315 \\
$\mathrm{OC}$ & 0.111 & 0.110 & 0.110 & 0.109 & 0.121 & 0.120 & 0.117 & 0.116 & 0.072 \\
BC & 0.136 & 0.135 & 0.131 & 0.131 & 0.146 & 0.146 & 0.133 & 0.133 & 0.088 \\
\hline
\end{tabular}



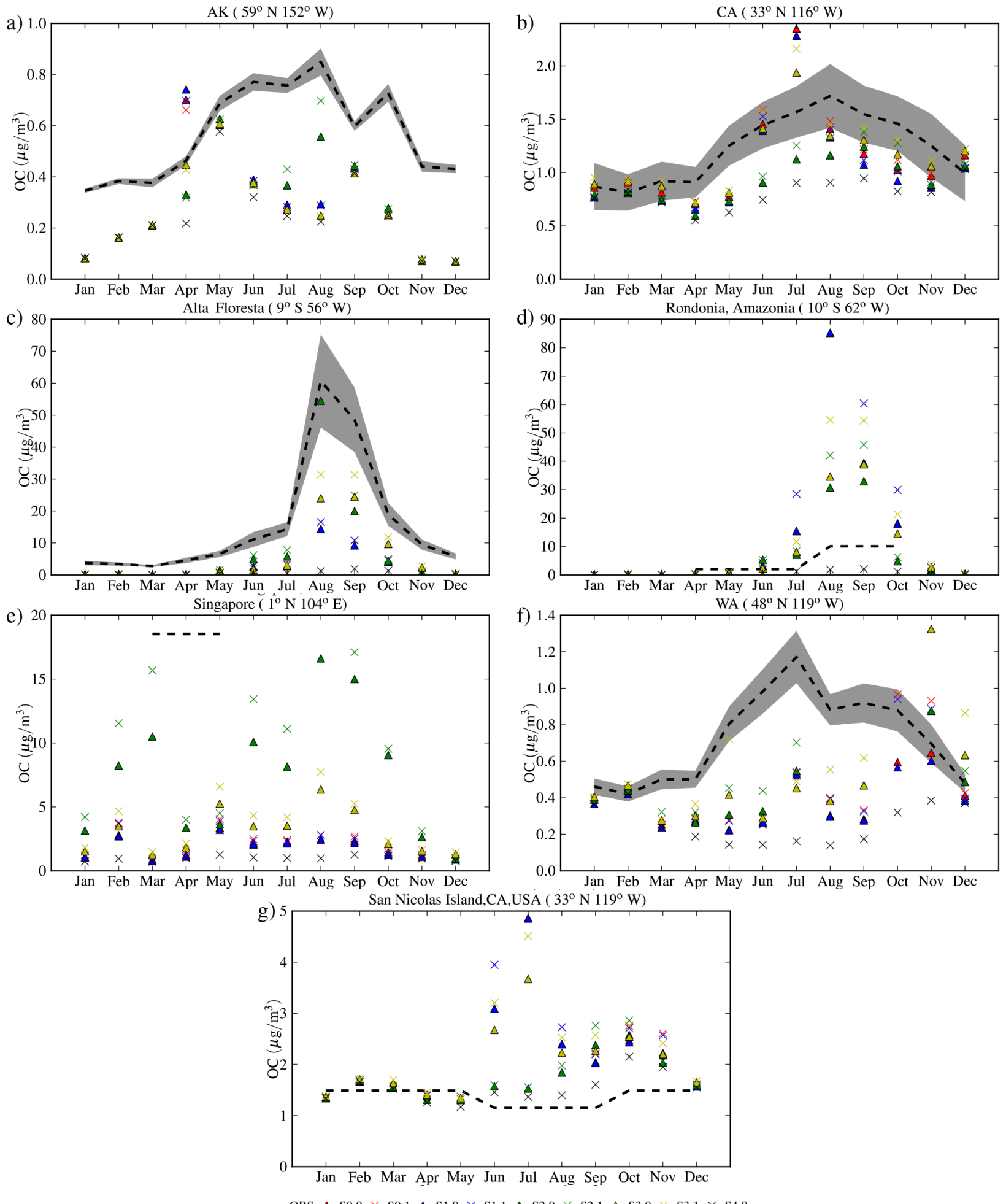

Figure 2. Comparison of monthly mean model results with observations of organic carbon (OC) at southern Alaska, USA (a); California, USA (b); Alta Floresta, Brazil (c); Rondonia, Amazonia, Brazil (d); Singapore (e); Washington State, USA (f); and San Nicolas Island, California, USA (g). The dashed line with the gray shaded area shows the monthly mean value of observations with the standard deviation based on their interannual variability, while the colored symbols show the calculated values for the specific station. Triangles are for simulations assuming a vertical distribution of wildfire emissions, while the $\times$ symbols show the simulations assuming that all open biomass burning emissions occur near the surface. Details on the simulations are given in Table 4. 

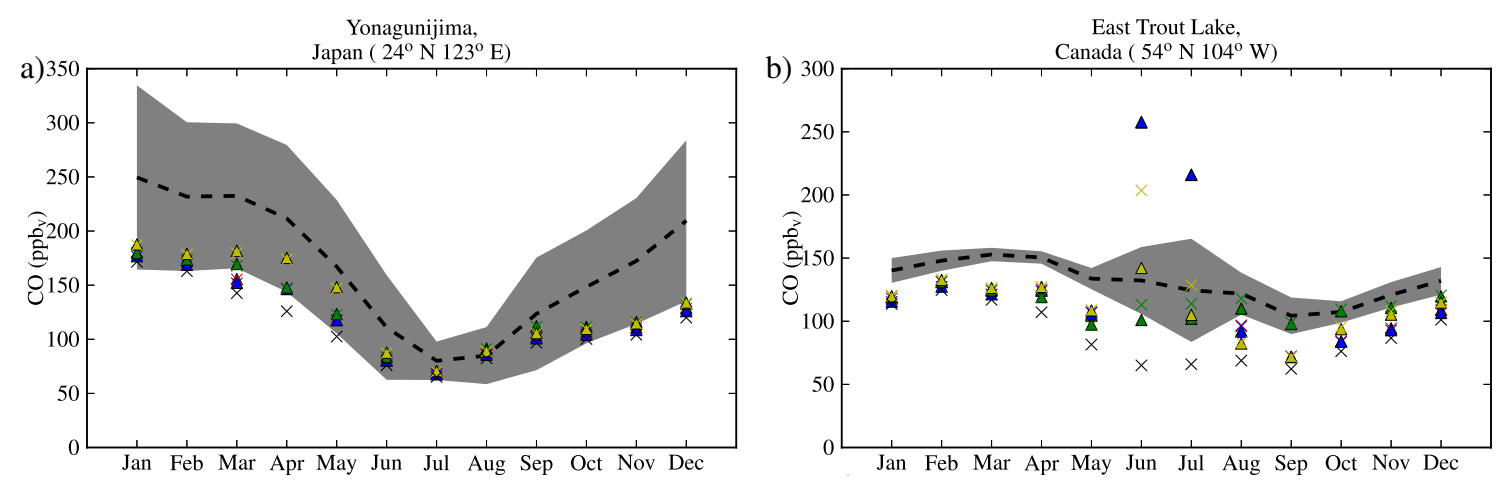

Figure 3. Comparison of monthly mean model results with CO surface observations at Yonagunijima, Japan (a), and at East Trout Lake, Canada (b). Lines and symbols as in Fig. 2 but for CO.

Fig. 4. Thus, evaluating these inventories requires densifying air quality monitoring close to the major biomass burning sources in the tropics, which are virtually absent. Furthermore, we have calculated the ratio of the standard deviation to the mean of all model simulations to identify locations where biomass burning emission inventories produce the largest model divergence. In Fig. 5 these ratios are shown for OC and indicate that systematic observations over boreal regions, Alaska, southern Asia and Indonesia can help to constrain the biomass burning emission inventories used.

\subsection{Comparison with ozonesondes and satellite observations}

Because the impact of biomass burning is not restricted into the surface concentrations of pollutants but also extends in the free troposphere, we have also compared model results with ozonesondes as well as with $\mathrm{O}_{3}$ and $\mathrm{CO}$ midtropospheric columns as observed by the tropospheric emission spectrometer (TES) satellite instrument. In addition, simulated $\mathrm{O}_{3}$ profiles have been compared with available ozonesonde data from WDCGG after interpolating into layers of $50 \mathrm{hPa}$ from the surface to the top of the atmosphere, as described in detail by Myriokefalitakis et al. (2015). Figure S6 shows that there is no statistical difference in the performance of the different scenarios with regard to ozonesonde observations.

Similar results are obtained from the comparison of model results to the TES global survey data version 4 with focus on the relatively sensitive middle/lower free troposphere, using data from seven TES pressure levels between 800 and $400 \mathrm{hPa}$. The TES products are provided in 67 levels in vertical with a varying layer thickness (Beer et al., 2001). In order to compare TM4-ECPL model results with the TES observations, the methods presented in Voulgarakis et al. (2011) have been used. Thus, the 3-hourly model outputs are sampled at the times and locations of the TES measurements, then they are interpolated onto the 67 TES pressure levels in vertical and, finally, the TES a priori profiles and averaging kernels are applied. The processed observational and model data are regridded to the original $3^{\circ} \times 2^{\circ}$ in longitude by latitude horizontal resolution in order to smooth out gaps in the observations. More details are provided in Myriokefalitakis et al. (2015) where a detailed model evaluation is presented including comparisons with satellite observations.

Point-by-point comparisons of the results for the different simulations performed for the present study against available TES observations for all model grids on daily mean basis are shown in Fig. S7. No simulation and thus no emission database stands out for its performance in reproducing the observations.

\subsection{Tropospheric loads}

The global annual mean tropospheric loads for selected gases and aerosol components as computed for the base case scenario (S0.0) are shown in Fig. 6 for $\mathrm{OC}, \mathrm{CO}, \mathrm{NO}_{\mathrm{x}}, \mathrm{O}_{3}, \mathrm{OH}$, and isoprene. Figure $\mathrm{S} 3$ shows similar results for $\mathrm{BC}, \mathrm{SO}_{4}^{2-}$, $\mathrm{NO}_{3}^{-}, \mathrm{HNO}_{3}$ and $\mathrm{NH}_{4}^{+}$. Although changes in the wildfire emissions do not significantly impact the global tropospheric load of most pollutants as shown in Table 5, regionally significant differences are computed (e.g., for BC, the difference can reach a factor of 7; Fig. S4b) as will be further discussed. The choice of wildfire emission inventory has an impact on the calculated tropospheric load of tracers. The most sensitive pollutants to wildfire emissions are found to be OC (Fig. S10) and $\mathrm{BC}$, while $\mathrm{O}_{3}$ shows small sensitivity.

\subsubsection{Contribution of wildfires emissions on tropospheric loads}

The contribution of wildfires to the tropospheric load of pollutants can be calculated by comparison of S0.0 (base case) with S4.0, which neglects the emissions. Wildfires increase the tropospheric loads of OC by $\sim 30 \%$, BC by $\sim 35 \%$, CO 

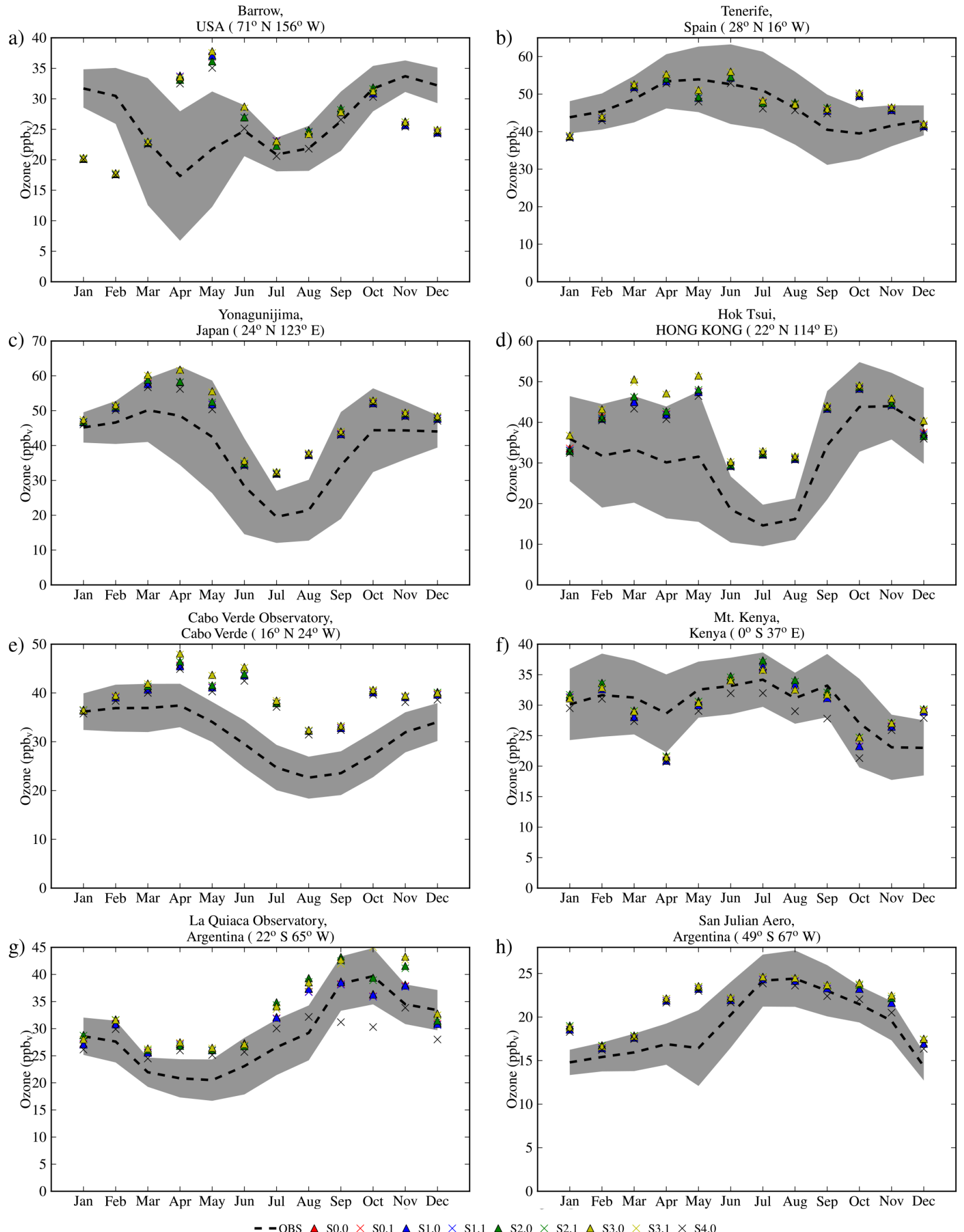

Figure 4. Comparison of monthly mean surface ozone measurements with model results at Barrow, USA (a); Tenerife, Spain (b); Yonagunijima, Japan (c); Hok Tsui, Hong Kong (d); Cabo Verde Observatory, Cabo Verde (e); Mount Kenya, Kenya (f); La Quiaca Observatory, Argentina (g); and San Julian Aero, Argentina (h). Lines and symbols as in Fig. 2 but for $\mathrm{O}_{3}$. 


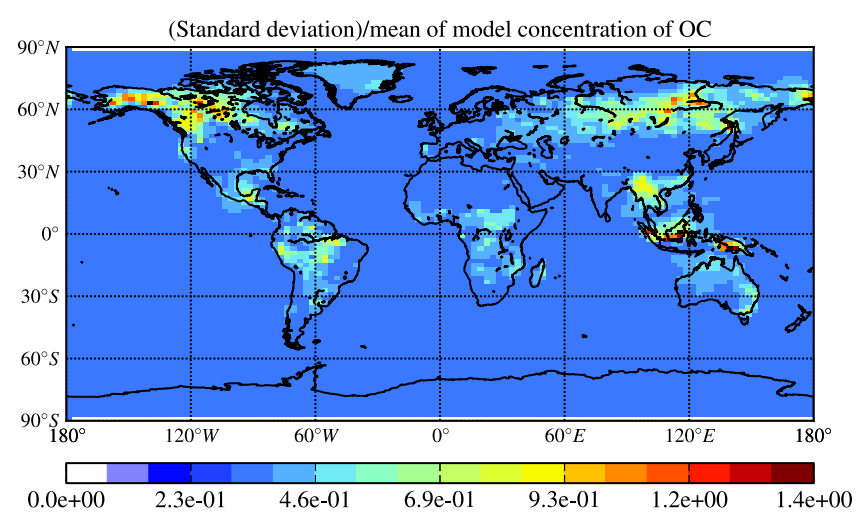

Figure 5. Spatial distribution of the ratio of the standard deviation to the mean of all model simulations, based on annual mean of the computed surface OC concentrations.

by $\sim 13 \%, \mathrm{NH}_{4}^{+}$by $10 \%, \mathrm{HNO}_{3}$ by $8 \%, \mathrm{NO}_{\mathrm{x}}$ by $5 \%$, and $\mathrm{SO}_{4}^{2-}$ and $\mathrm{O}_{3}$ by $3 \%$ (Table 5).

Previous studies for CO with the NOAA GFDL GCTM have shown biomass burning to contribute from 15 to $30 \%$ of the total CO background (Galanter et al., 2000). This is in agreement with the measurements by Crounse et al. (2009) in central Mexico which attributed $21-31 \%$ of the CO load to biomass burning emissions. This impact presents large temporal and spatial variability since it occurs during the burning season that lasts only a few months per year and is marked by tropical and boreal forest fires. The Ziemke et al. (2009) modeling study with the Global Modeling Initiative (GMI) chemical transport model shows a global increase in $\mathrm{CO}$ between 21 and $53 \%$ due to biomass burning. The tropospheric $\mathrm{O}_{3}$ load has been shown to correlate with that of $\mathrm{CO}$ during biomass burning events with a slope of $\mathrm{O}_{3} / \mathrm{CO}$ of about 1 (Honrath et al., 2004). However, other studies have shown only small changes in the tropospheric ozone on a global scale (4-5\% increase computed by Ziemke et al., 2009) where, regionally, different impacts are computed, ranging from 10 to $40 \%$ increase depending on region and season (Galanter et al., 2000). Aircraft observations in boreal Canada showed no distinguishable differences between the smoke plume and the clean air concentrations (Parrington et al., 2013), while substantial $\mathrm{O}_{3}$ enhancement has been measured in air masses downwind of fire locations (Palmer et al., 2013).

The spatial variability of the annual mean impact of wildfire emissions on the tropospheric loads of $\mathrm{OC}, \mathrm{CO}, \mathrm{NO}_{\mathrm{x}}, \mathrm{O}_{3}$, $\mathrm{OH}$ and isoprene is depicted in Fig. 7a-f and on $\mathrm{BC}, \mathrm{SO}_{4}^{2-}$, $\mathrm{NO}_{3}^{-}, \mathrm{HNO}_{3}$ and $\mathrm{NH}_{4}^{+}$in Fig. S5a-e. The most affected pollutants are OC (Fig. 7a) and BC (Fig. S5a) with a computed local reduction due to the omission of wildfires by almost $100 \%$, which is in agreement with previous studies where a reduction of $50 \%$ has been measured in Beijing (Duan et al., 2004), and of up to $66 \%$ in central Mexico (Crounse et al., 2009). Our results also show that annual mean local impacts on $\mathrm{O}_{3}$ and $\mathrm{CO}$, pollutants that have strong secondary sources, maximize at $20-30 \%$ in the tropics. As expected, the $\mathrm{NO}_{\mathrm{x}}$ tropospheric load is mostly affected by biomass burning both in the extratropics since fires contribute by $50 \%$ to the $\mathrm{NO}_{\mathrm{x}}$ load at the outflow of boreal fires and in the tropical regions of South America, Africa and northern Australia where burning is significant (Fig. 7c), in agreement with previous studies that show up to $75 \%$ reduction near equatorial Africa (Galanter et al., 2000). As a consequence of the $\mathrm{NO}_{\mathrm{x}}$ and $\mathrm{O}_{3}$ reductions when fire emissions are omitted, the computed hydroxyl radical $(\mathrm{OH})$ load (Fig. 7e) is significantly reduced (5-10\%) over the same regions; while larger percent reductions are computed at high northern latitudes where $\mathrm{OH}$ loads are generally very low due to the very weak photochemistry there.

\subsubsection{Impact of injection height}

The effect of height distribution of wildfire emissions on the computed tropospheric loads has been studied by comparing the simulations SX.0 with the respective simulations SX.1. Figure 8 presents such comparisons for BC. Both OC and $\mathrm{BC}$ are strongly affected by the injection height parameterization, since emitting aerosols above the boundary layer reduces aerosols available near the surface for loss via dry deposition. The largest differences are computed for the high latitudes over North America and China where emission height distribution assumptions can result in differences of about $25 \%$ (Fig. 8). Previous studies conducted with the GEOS-Chem model for southeastern Asia during 2001 show a decrease of $20-40 \%$ of BC surface concentrations when injected at height (Jian and $\mathrm{Fu}, 2014)$. In the same study it is shown that biomass burning injection height has a much larger impact on $\mathrm{BC}$ than $\mathrm{CO}(50-150 \%$ more $\mathrm{BC}$ calculated at $700 \mathrm{hPa}$, than when emitted in the boundary layer). Differences are positive over source areas (since more is emitted near the surface in SX.1) and negative downwind (since less is transported away from source regions due to the increased deposition flux at the source regions). Additional comparisons are presented in Fig. S8a-f). Assumptions in the biomass burning emissions injection height marginally affect $\mathrm{CO}$ and $\mathrm{O}_{3}$, with computed differences in the global annual mean tropospheric load smaller than $2.5 \%$.

\subsubsection{Chemical interactions between biomass burning and vegetation emissions}

It is interesting to examine the impact of wildfire emissions on isoprene tropospheric load. Isoprene is the single most important BVOC emitted by vegetation (more than $50 \%$ of total annual BVOC emissions). The changes in $\mathrm{OH}$ described in Sect. 4.3.1 (Fig. 7e), the main tropospheric oxidant that consumes isoprene, led to opposite sign changes of isoprene (Fig. 7f). Such results indicate a strong chemical interaction between biomass burning and species emitted by vegetation. 

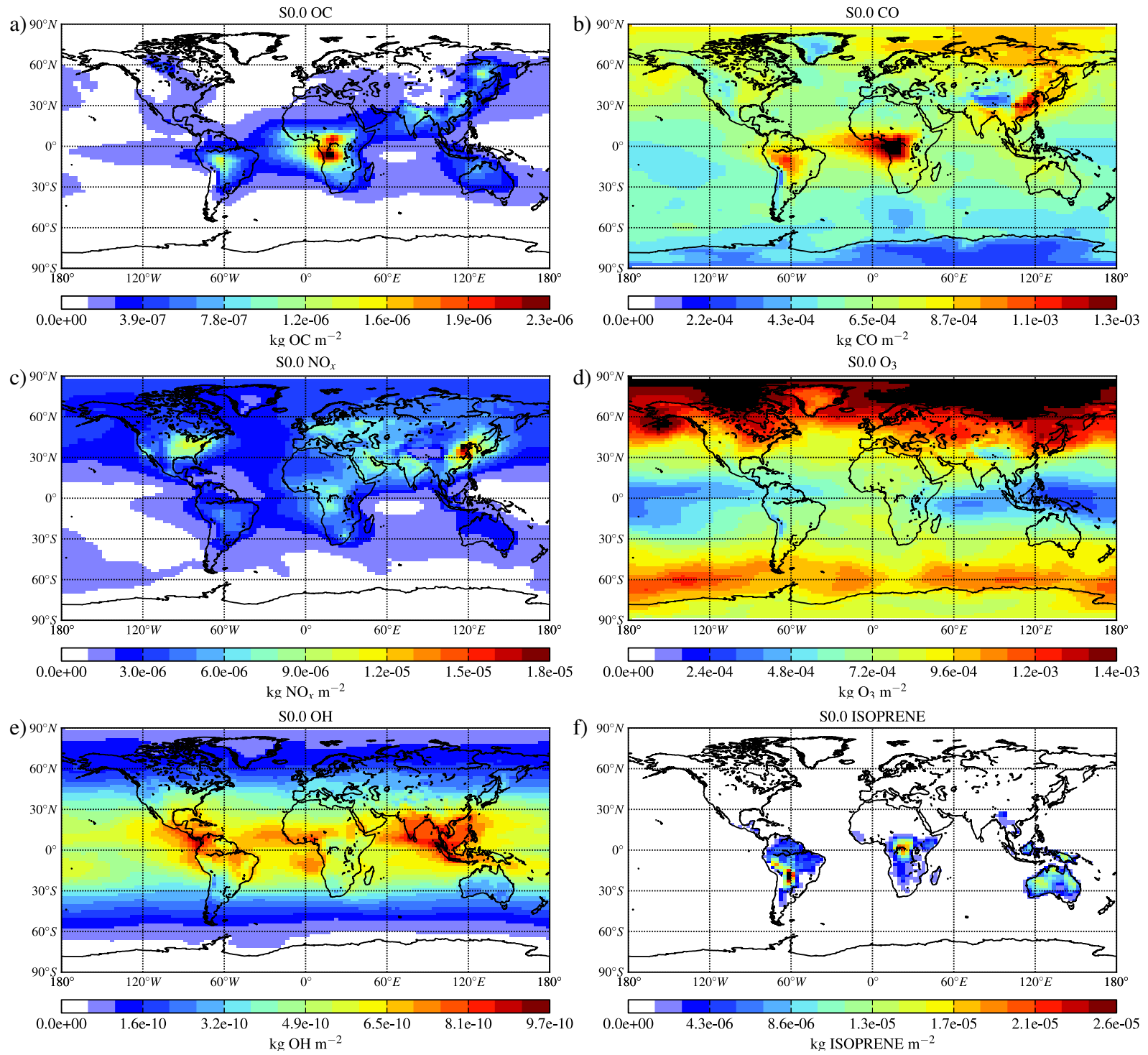

Figure 6. Calculated annual mean tropospheric load in $\left(\mathrm{Kg} \mathrm{m}^{-2}\right)$ of selected species for the base case scenario (S0.0). Areas with black exceed the maximum value of the color bar.

These interactions are linking isoprene destruction and aerosol formation via the oxidants (hydroxyl-OH- and nitrate- $\mathrm{NO}_{3}$ - radicals and ozone) that consume isoprene and produce semivolatile organics but also via primary biomass burning aerosols that provide a surface for organics to condense on. In the presence of fires, for the same isoprene emissions from vegetation more nitrogen oxides $\left(\mathrm{NO}_{\mathrm{x}}\right)($ Fig. $7 \mathrm{c})$ are emitted, leading to higher $\mathrm{OH}$ radicals in the extended biomass burning region (up to $20 \%$ regionally, Fig. 7e) and slightly lower over Northern Hemisphere regions with intensive anthropogenic $\mathrm{NO}_{\mathrm{x}}$ emissions and their outflow. Thus, isoprene ambient levels are reduced with the highest reduction over and downwind of tropical forested areas. The isoprene global tropospheric column is calculated to be lower by $15 \%$ in S0.0 than in S4.0 (Fig. 7f). However, due to the $\mathrm{NO}_{\mathrm{x}}$-dependence of the semivolatile organic compound formation from isoprene oxidation, the total isoprene-SOA concentrations change little $(2 \%)$. This implies an overall $13 \%$ reduction in semivolatile organic compounds formation yield from isoprene oxidation that comes to compensate for the increased isoprene oxidation. In addition, the primary organic aerosols (POAs) emitted by biomass burning provide the surface for partitioning of semivolatile compounds, thus, significantly increasing the partitioning of organic vapors to the aerosol phase that in turn also stimulate further partitioning to the aerosol phase. Thus, the isopreneSOA partitioning to the aerosol phase increases by $16 \%$ in depletion of the gas phase isoprene-SOA precursors. This enhancement is consistent with, although much lower than, the results derived by Kanakidou et al. (2000) on the enhance- 

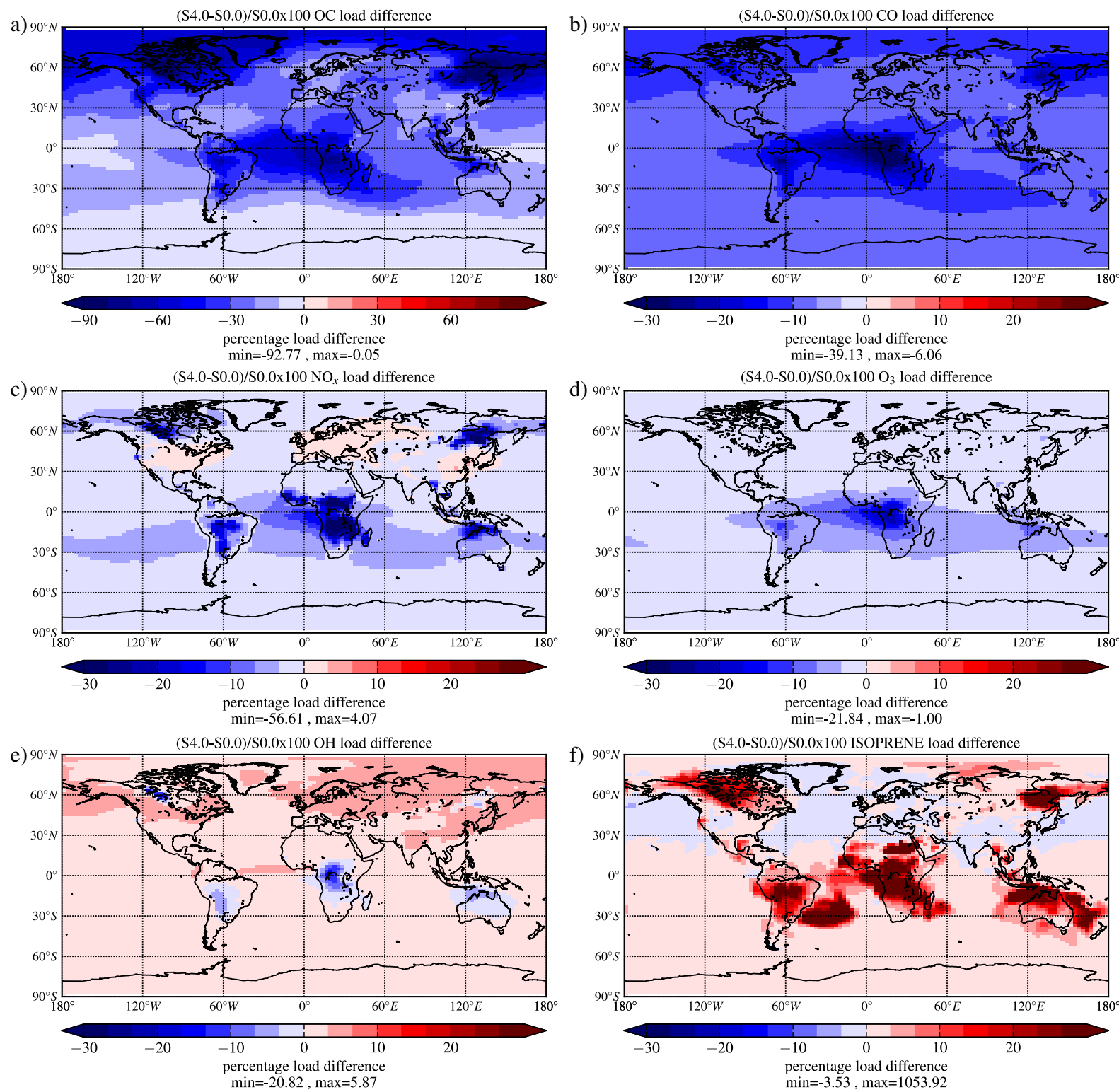

Figure 7. Percentage difference in the computed annual mean tropospheric loads of $\mathrm{OC}(\mathbf{a}), \mathrm{CO}(\mathbf{b}), \mathrm{NO}_{\mathrm{x}}(\mathbf{c}), \mathrm{O}_{3}(\mathbf{d}), \mathrm{OH}_{(\mathbf{e}), \text { and isoprene }}$ (f) - attributed to wildfire emissions calculated as (column_S4.0 - column_S0.0)/(column S0.0) $\times 100$. The scale is from -30 to $30 \%$ ( -90 to $90 \%$ for OC); the minimum and maximum differences are printed below each panel.

ment of SOA formation from biogenic VOC due to partitioning on POA from pollution sources. That earlier study used higher aerosol yields from BVOC than here and did not account for the later studied $\mathrm{NO}_{\mathrm{x}}$ dependence of these yields; it also presented changes due to both combustion and fossil fuel POA. It has also shown that the use of different parameters in the two products yields a representation of SOA formation from BVOC which can lead to up to $70 \%$ of differences in the computed SOA tropospheric burden, depending on atmospheric conditions. Tsigaridis et al. (2006) have evaluated the importance of the consideration of $\mathrm{NO}_{\mathrm{x}}$-dependent SOA formation by calculating changes in the SOA burden and characteristics and found that in the current troposphere about $72 \%$ of the total SOA mass is formed under $\mathrm{NO}_{\mathrm{X}}$ driven chemistry while in the past this fraction was lower $(48 \%)$. Note, however, that large uncertainties and gaps in knowledge exist in the kinetics of isoprene-aerosol formation. Rollins et al. (2009) studied the $\mathrm{NO}_{3}$ radical-driven chemistry of isoprene-SOA formation. They demonstrated the complexity of isoprene chemistry with respect to SOA formation with a drastic increase in aerosol yield when both double bounds of isoprene are oxidized, thus, documenting the aerosol yield dependence on the level of oxidation of the precursors. The investigations of Ervens et al. (2008) 


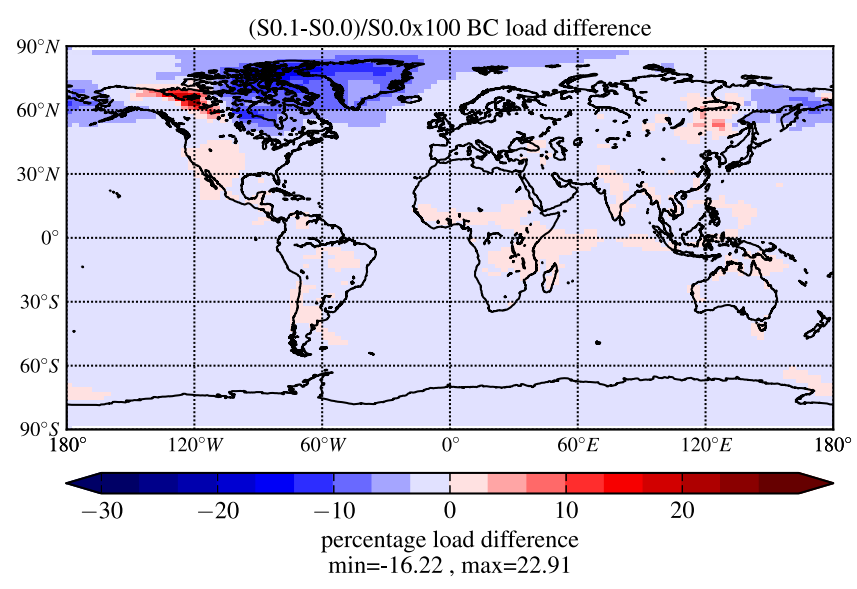

Figure 8. Percentage difference of annual mean computed tropospheric load of BC attributed to wildfire emission injection height calculated as (load_S0.1-load_S0.0)/(load S0.0) $\times 100$. The scale is from -30 to $30 \%$; the minimum and maximum percentage differences are printed below the figure.

show that isoprene aqueous phase chemistry is more efficient (about $40 \%$ aerosol yield) than gas phase chemistry (about $3 \%$ of aerosol yield) in forming SOA and depends on the water content in the atmosphere and $\mathrm{pH}$. The Carlton et al. (2009) review of laboratory measurements, field experiments and modeling studies concerning SOA formation from isoprene, documented differences in SOA yield parameterizations that mostly rely on a single set of chamber experiments, while aerosol yields are known to depend on various factors including the relative importance of $\mathrm{NO}_{\mathrm{x}}$ versus peroxide chemistry, temperature (which affects the aerosol components' volatility based on their enthalpy of vaporization) and pre-existing aerosol loading. They calculated differences in SOA load induced by the $\mathrm{NO}_{\mathrm{x}}$ dependence parameterizations that are up to $30 \%$ of the total simulated OA over the eastern USA.

This feedback in the presence of biomass burning emissions increases by about $18 \%$ the global mean aerosol yield from isoprene emissions that is defined as the ratio of the tropospheric load of secondary organic aerosol from isoprene oxidation to the emissions of isoprene, while locally this difference can exceed $40 \%$. Impacts on the tropospheric loads of the first-generation gaseous products of isoprene are smaller, i.e., about $10 \%$. Figure S11 shows the spatial distribution of the percentage changes in the aerosol yield from isoprene emissions as computed comparing simulations S4.0 and S0.0. This figure points to the areas where the impact of biomass burning emissions (in percentage) on the apparent SOA yield from isoprene is calculated by our model to be significant. These areas are the high-latitude zones of North America and Asia, the tropical regions over land as well as the outflow from biomass burning regions. Note, however, that most isoprene-SOA formation occurs over land.
Our results demonstrate the strong coupling between tropospheric chemistry, biomass burning and vegetationemitted species. They show that it is critical for the evaluation of the impact of these emissions on tropospheric chemistry to consistently account for BVOC emissions from vegetation and the co-location/co-occurrence of biomass burning emissions in the area. The co-location of vegetation and biomass burning emissions is linked to the model grid size since colocation area increases with lowering the horizontal resolution of the model. In this respect, to further investigate the impact of the feedback strength to the model resolution, a lower-resolution set of simulations has been also performed. These low-resolution simulations give results similar to the higher resolution with regard to the feedback strength (relative changes between S0.0 and S4.0). Thus, the percentage of increases do not seem to be affected by the resolution of the model, while the computed tropospheric loads of isoprene and secondary organic aerosol differ between the high- and low-resolution simulations with low-resolution simulations computing approximately $10 \%$ lower SOA and $4 \%$ lower isoprene loads.

\subsection{Tropospheric lifetimes}

The lifetimes of pollutants provide a measure of pollutant persistence in the atmosphere. Here they are computed as the ratio of the tropospheric load to the loss rate (sum of chemical loss and deposition fluxes) for each model column (lowest 22 vertical layers of the model). Global mean tropospheric lifetimes are derived from the computed global burdens and losses. Changes in chemistry as discussed above, as well as changes in deposition of pollutants due to the modification of their spatial distribution, affect the lifetime of these compounds in the troposphere. Thus, isoprene's lifetime is increased in S4.0, as previously explained, by almost $20 \%$ compared to S0.0. The global tropospheric lifetimes of all other species are less impacted by the choice of the emission inventory, with a maximum of about $12 \%$ for OC. This is in agreement with previously calculated differences reported in the literature. For instance, such differences resulting from the use of three different biomass burning inventories (two global and one regional) in the TM4 model coupled with the CBM4 chemical mechanism do not exceed $5 \%$ for the African domain (Williams et al., 2012). Table 6 shows the calculated global tropospheric lifetimes of pollutants for each scenario. The maximum percentage differences from the base case scenario (S0.0) are computed for the S4.0 simulation that neglects all wildfire emissions.

The lifetimes of pollutants, computed as the ratio of the tropospheric load to the loss rate (sum of chemical loss and deposition fluxes) for each model column, show sensitivity to both the height distribution of the emissions and the different emission inventories. The sensitivity of the OC lifetime to the height of injection of the biomass burning emissions is depicted in Fig. 9, where the difference in calculated 


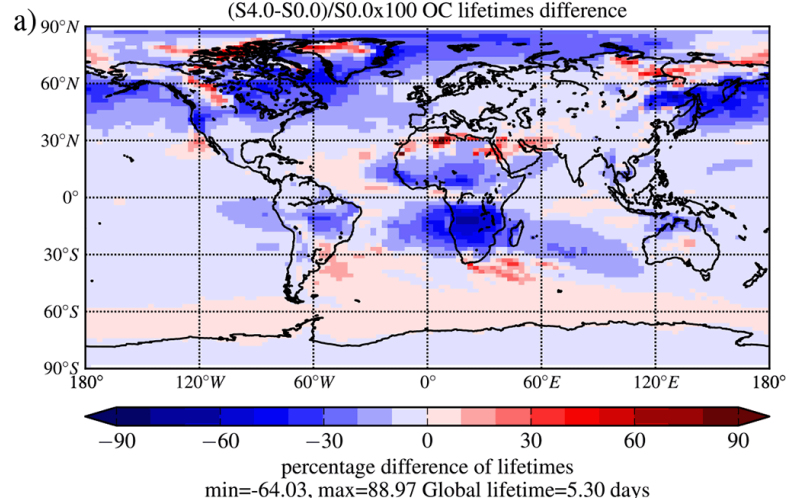

(S1.0-S0.0)/S0.0x100 OC lifetimes difference

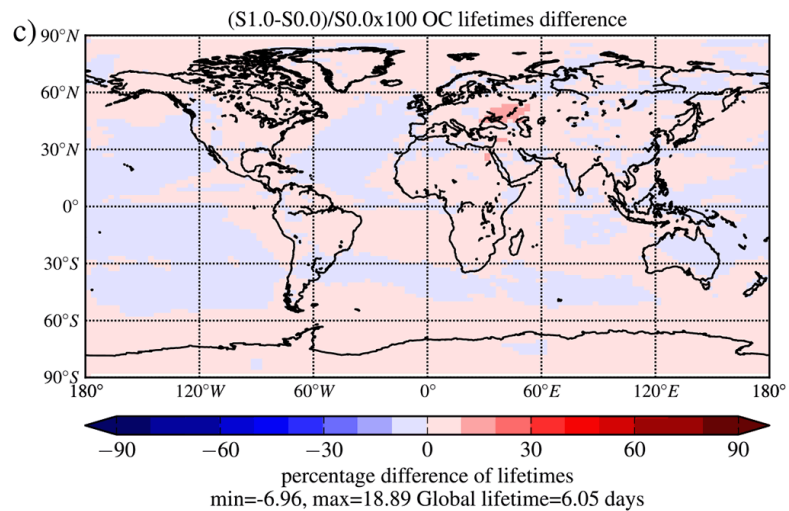

(S2.0-S0.0)/S0.0x100 OC lifetimes difference

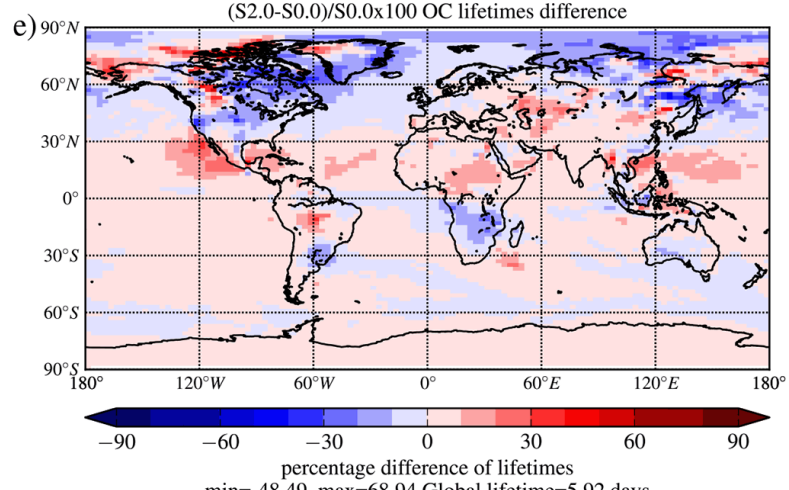

$\min =-48.49, \max =68.94$ Global lifetime $=5.92$ days

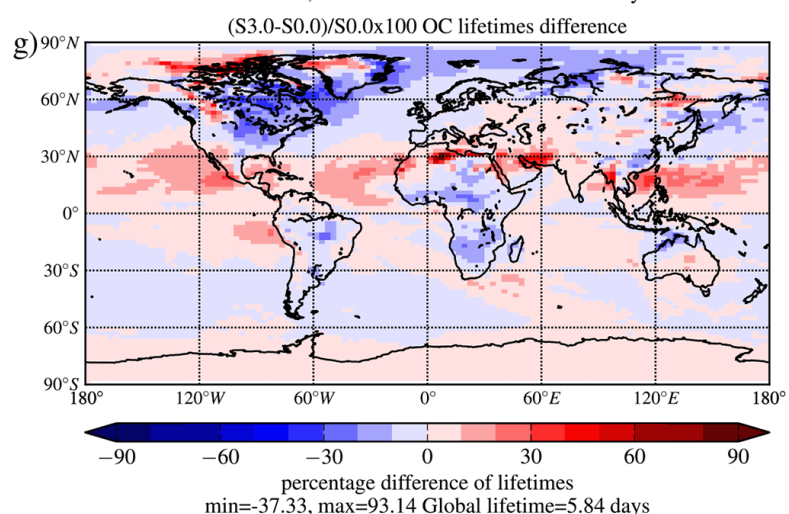

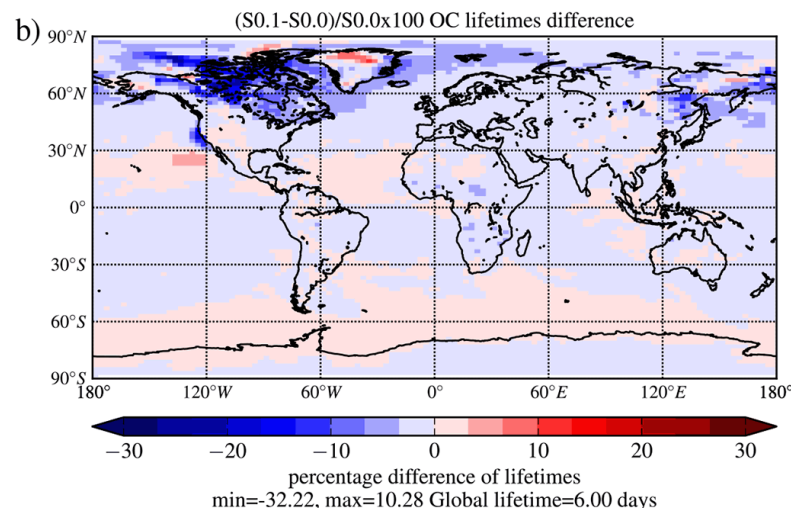

$\min =-32.22, \max =10.28$ Global lifetime $=6.00$ days

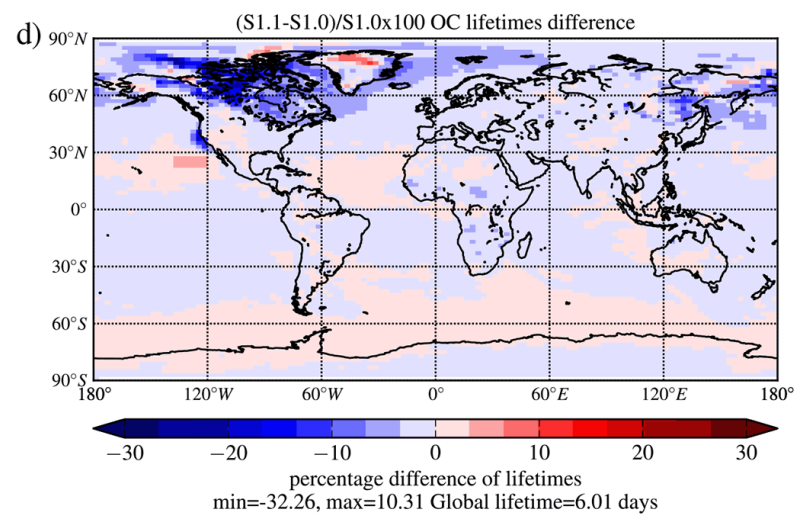

(S2.1-S2.0)/S2.0x100 OC lifetimes difference

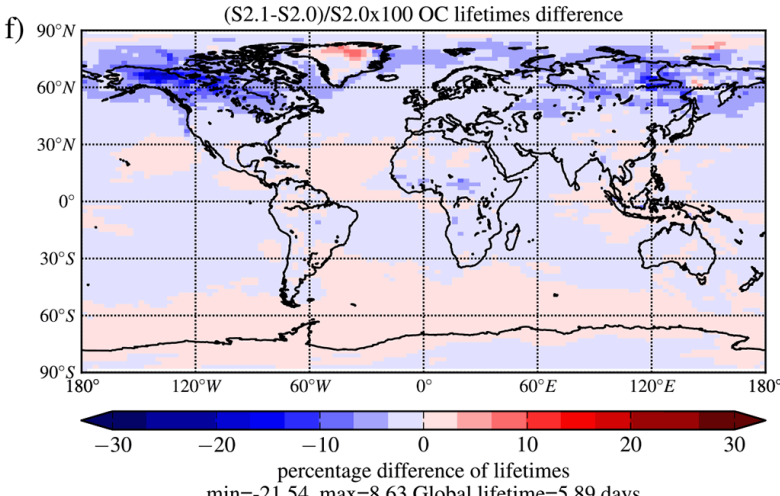

$\min =-21.54, \max =8.63$ Global lifetime $=5.89$ days

(S3.1-S3.0)/S3.0x100 OC lifetimes difference

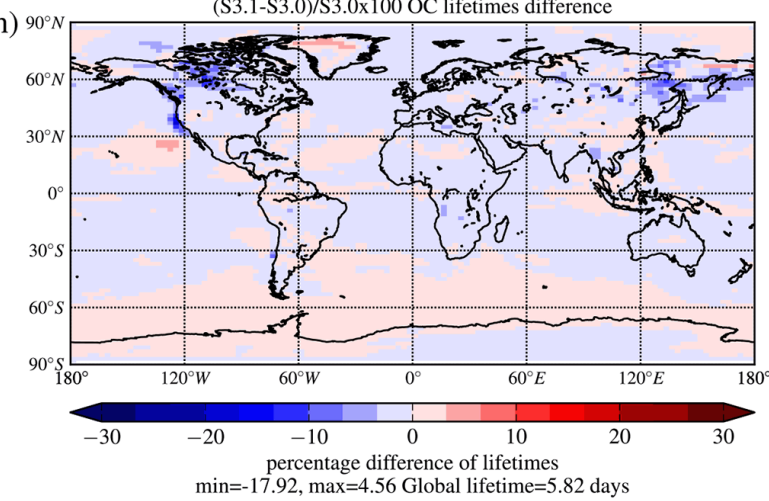

Figure 9. Percentage of impact on the computed annual mean tropospheric lifetime of OC of (left panels) the different emission inventories calculated as the percentage difference between simulations SX.0 and simulation S0.0, and of (right panels) height distribution calculated as the percentage difference between simulations SX.1 and simulations SX.0. The color bar ranges from -90 to $90 \%$ for the surface differences and -30 to $30 \%$ for the differences induced by height distribution. The minimum and maximum local lifetime percentage changes as well as the global lifetime are printed below each panel. 

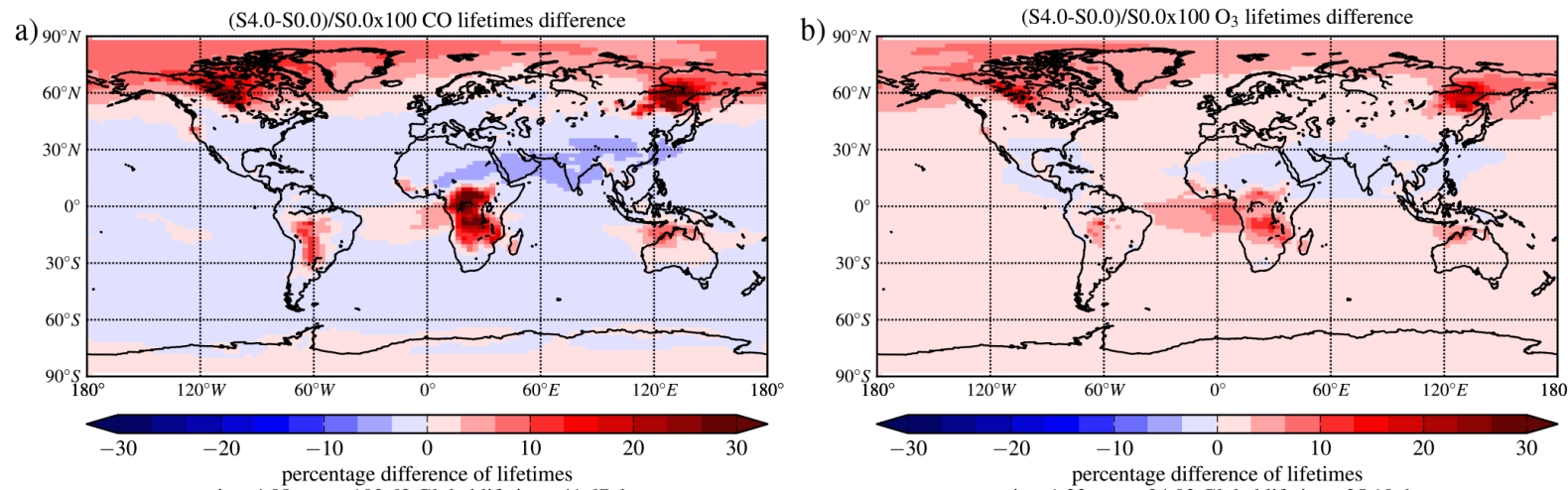

$\min =-4.88, \max =102.63$ Global lifetime $=41.67$ days
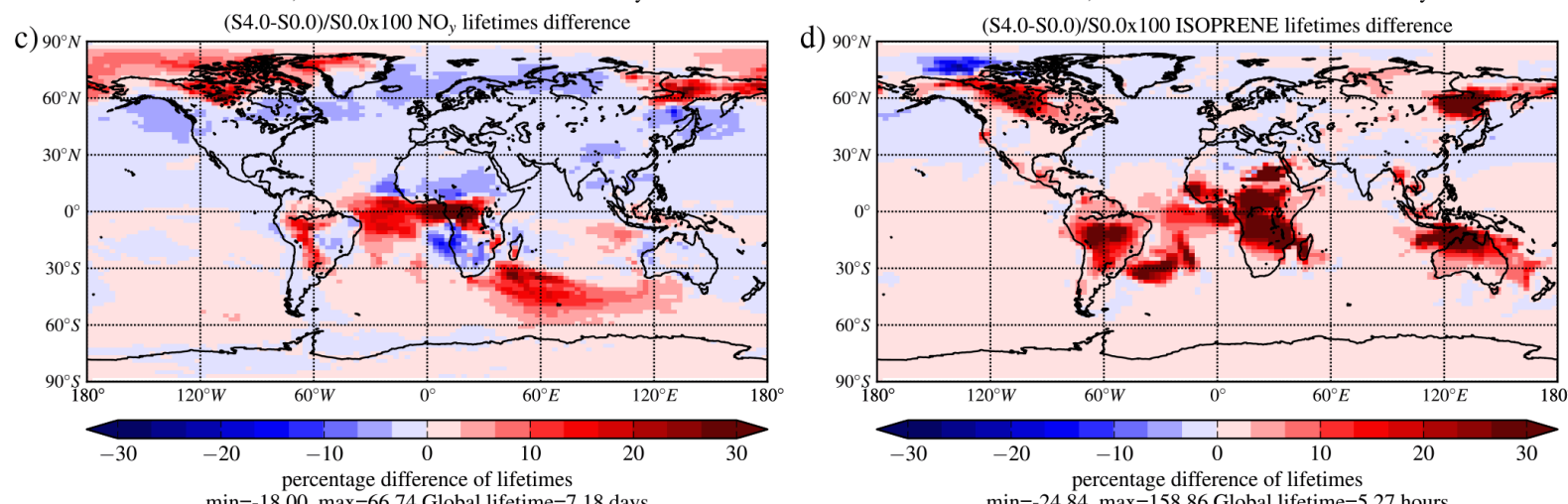

in $=-18.00, \max =66.74$ Global lifetime $=7.18$ days

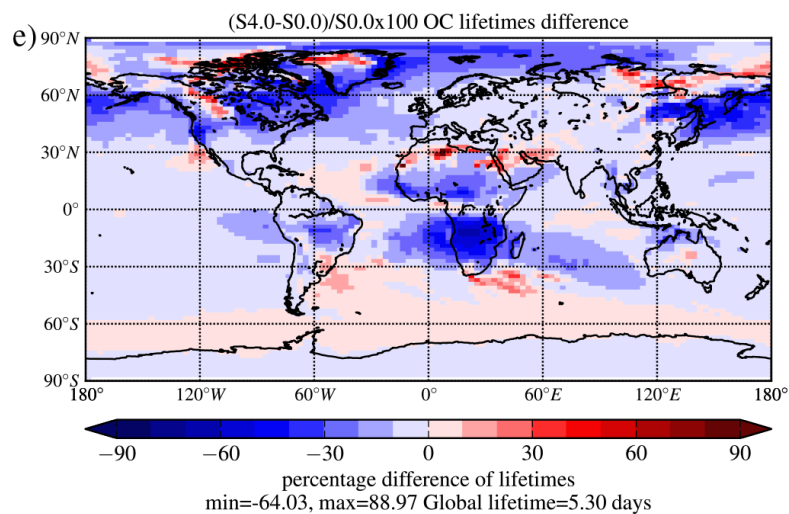

$\min =-24.84, \max =158.86$ Global lifetime $=5.27$ hours

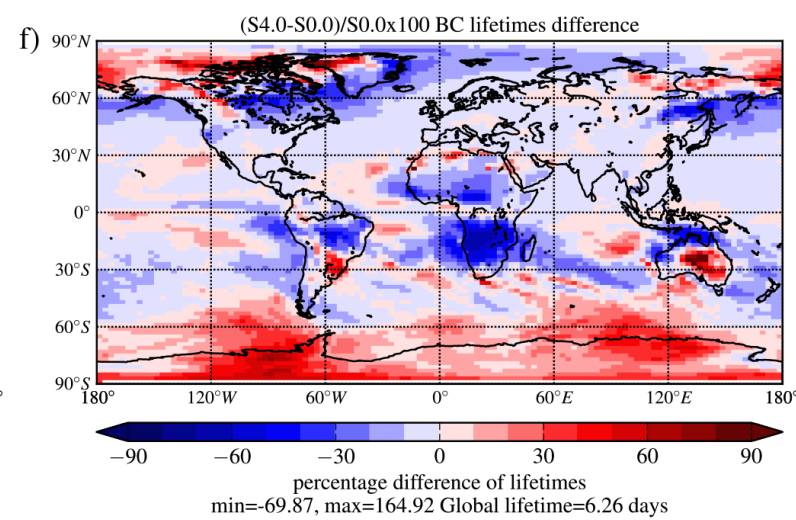

(S4.0-S0.0)/S0.0x100 $\mathrm{SO}_{4}^{--}$lifetimes difference

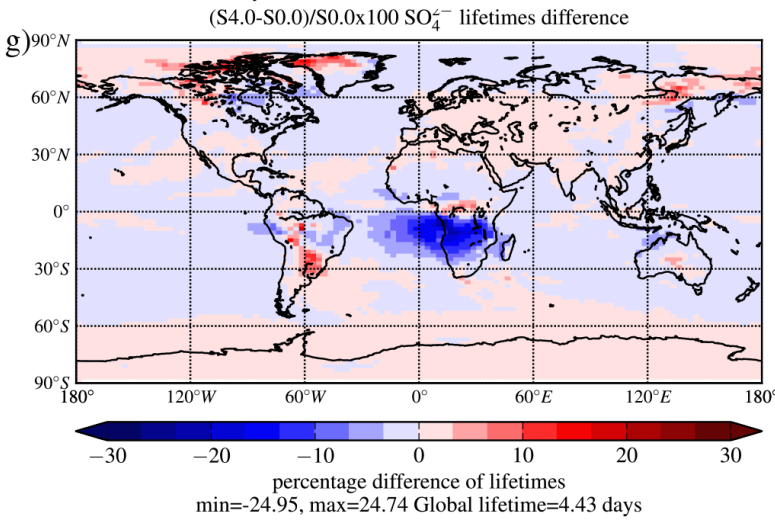

Figure 10. Percentage of impact of wildfire emissions on the computed annual mean tropospheric lifetimes of $\mathrm{CO}(\mathbf{a}), \mathrm{O}_{3}(\mathbf{b}), \mathrm{NO}_{\mathrm{y}}(\mathbf{c})$, isoprene (d), OC (e), $\mathrm{BC}(\mathbf{f})$ and $\mathrm{SO}_{4}^{2-}$ (g) depicted as the percentage difference of S4.0 and S0.0. The color bar ranges from -30 to $30 \%$ ( -90 to $90 \%$ for $\mathrm{OC}$ and $\mathrm{BC}$ ). The minimum and maximum local lifetime percentage changes as well as the global lifetime are printed below each panel. 

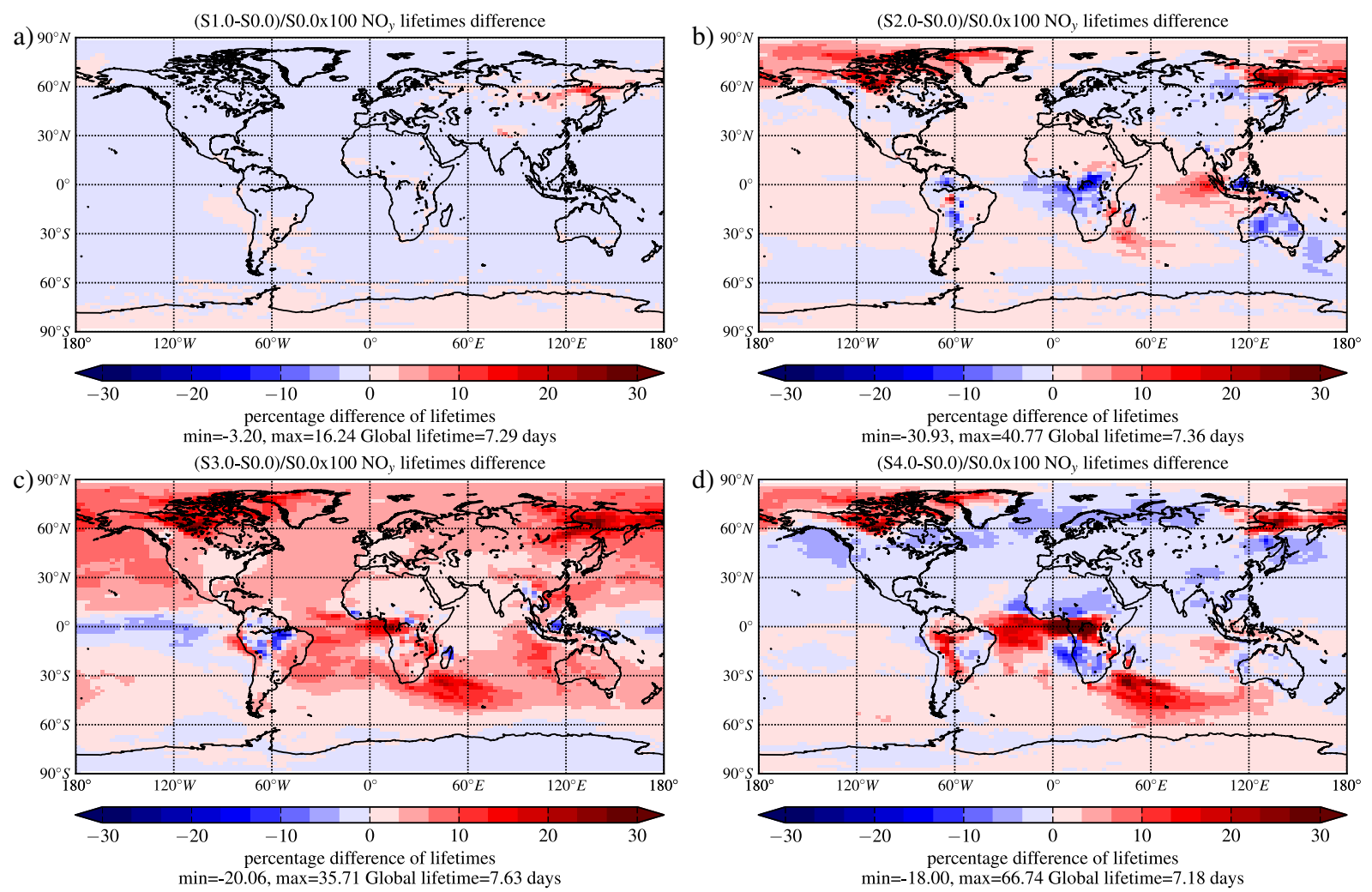

Figure 11. Computed annual mean tropospheric $\mathrm{NO}_{\mathrm{y}}$ lifetime differences between the base case scenario (S0.0) and S1.0 (a), S2.0 (b), S3.0 (c) and S4.0 (d), computed by reference to S0.0. The color bar ranges from -30 to $30 \%$. The minimum and maximum local lifetime percentage changes as well as the global lifetime are printed below each panel.

Table 6. Calculated annual mean tropospheric lifetimes of pollutants for all the simulations performed.

\begin{tabular}{lrrrrrrrrr}
\hline & $\mathrm{S} 0.0$ & $\mathrm{~S} 0.1$ & $\mathrm{~S} 1.0$ & $\mathrm{~S} 1.1$ & $\mathrm{~S} 2.0$ & $\mathrm{~S} 2.1$ & $\mathrm{~S} 3.0$ & $\mathrm{~S} 3.1$ & $\mathrm{~S} 4.0$ \\
\hline $\mathrm{CO}$ (days) & 41.48 & 41.44 & 41.43 & 41.35 & 41.82 & 41.67 & 41.45 & 41.40 & 41.67 \\
$\mathrm{O}_{3}$ (days) & 24.58 & 24.62 & 24.59 & 24.63 & 24.39 & 24.43 & 24.33 & 24.39 & 25.19 \\
$\mathrm{NO}_{\text {y }}$ (days) & 7.342 & 7.300 & 7.293 & 7.255 & 7.358 & 7.297 & 7.628 & 7.541 & 7.184 \\
$\mathrm{SO}_{4}^{2-}$ (days) & 4.446 & 4.442 & 4.448 & 4.444 & 4.427 & 4.423 & 4.421 & 4.419 & 4.426 \\
$\mathrm{HNO}_{3}$ (days) & 2.804 & 2.805 & 2.793 & 2.800 & 2.792 & 2.796 & 2.774 & 2.775 & 2.776 \\
$\mathrm{NH}_{4}^{+}$(days) & 4.979 & 4.932 & 5.032 & 4.962 & 4.961 & 4.905 & 4.928 & 4.894 & 4.862 \\
$\mathrm{Isoprene} \mathrm{(hours)}$ & 4.457 & 4.475 & 4.466 & 4.482 & 4.137 & 4.152 & 4.236 & 4.250 & 5.270 \\
$\mathrm{OC}$ (days) & 6.031 & 5.998 & 6.046 & 6.012 & 5.925 & 5.894 & 5.839 & 5.819 & 5.302 \\
$\mathrm{BC}$ (days) & 6.927 & 6.908 & 6.962 & 6.941 & 6.889 & 6.871 & 6.583 & 6.572 & 6.261 \\
\hline
\end{tabular}

tropospheric lifetimes of OC attributed to emission injection height alone can reach $30 \%$ (right panels). The differences produced by injection height for other species are provided in Fig. S9. The use of different biomass burning emission inventories led to up to almost $90 \%$ of the local differences for OC as seen in Fig. 9g. The maximum differences are computed in the tropics and over the boreal forests in Canada and eastern Russia using the ACCMIP and FINN inventories (Fig. 9e, g). The overall impact of biomass burning emissions (simulations S4.0 versus S0.0) on the regional lifetimes of tracers is shown in Fig. 10, where significant increases in $\mathrm{O}_{3}$ (up to about $25 \%$ ) and $\mathrm{CO}$ (up to about a factor of 2) lifetimes are calculated when wildfire emissions are neglected. Biomass burning reduces the $\mathrm{O}_{3}$ lifetime in the burning regions of the tropics and the boreal forests. This is mainly due to the reaction of $\mathrm{O}_{3}$ with $\mathrm{NO}$ emissions and subsequent $\mathrm{HNO}_{3}$ formation. The impact of fire emissions on chemistry can be seen through the increases in the regional lifetime of $\mathrm{CO}$ and isoprene in S4.0 (Fig. 10a, d), where local differences can reach $160 \%$. OC and $\mathrm{BC}$ lifetimes are highly affected with local computed differences of up to almost $90 \%$ (OC) and $150 \%$ (BC) (Fig. 10e-f). Similar results are produced for 
$\mathrm{SO}_{4}^{2-}$ lifetimes, where the local differences in calculated tropospheric lifetimes range from about -25 to $25 \%$ near the tropics (Fig. 10g) and above the boreal forests of Russia and Canada where most open biomass burning events occur. Note that aerosol species like OC and BC have significant primary emissions from biomass burning and are removed from the atmosphere by dry and wet deposition, while carbon monoxide, isoprene, and $\mathrm{O}_{3}$ loads and lifetimes are driven by strong chemical production and loss terms. Thus, aerosol species behave differently than these short-lived chemically reactive gases.

The tropospheric $\mathrm{NO}_{\mathrm{y}}$ lifetime $\left(\mathrm{NO}_{\mathrm{y}}\right.$ is the sum of $\mathrm{NO}_{\mathrm{x}}$, $\mathrm{HNO}_{3}$, peroxyacetyl nitrate and organic nitrates) due to depositional losses strongly responds to the wildfire emissions used in the model, with differences between about -40 and $70 \%$ when taking into account all simulations that have been performed for this study. Focusing on central Canada and northeastern Asia, the S2.0 simulation results in a large increase in $\mathrm{NO}_{\mathrm{y}}$ lifetime compared to $\mathrm{S} 0.0$ (Fig. 11b) that is weaker for the S1.0 (Fig. 11a). These differences are mainly attributed to the spatial distribution of the emissions favoring different chemistry pathways and resulting in different fractional composition of $\mathrm{NO}_{\mathrm{y}}$ and, thus, different dry and wet removal fluxes. Note that high differences in $\mathrm{NO}_{\mathrm{y}}$ lifetime due to deposition are calculated over the tropical regions with both positive and negative differences over and offshore of tropical Africa. There, both $\mathrm{NO}_{\mathrm{y}}$ burden and deposition losses increase due to biomass burning emissions and the corresponding $\mathrm{NO}_{\mathrm{y}}$ lifetime in $\mathrm{S} 0.0$ varies roughly between 4 and 50 days (Fig. S12a). When wildfire emissions are omitted in the model, the absolute differences in $\mathrm{NO}_{\mathrm{y}}$ lifetime between simulations $\mathrm{S} 4.0$ and S0.0 in the tropics vary from -6.5 to +5 days (Fig. $\mathrm{S} 12 \mathrm{~b}$ ). Thus, the $\mathrm{NO}_{\mathrm{y}}$ lifetime increases by up to $67 \%$ locally (Fig. 11d), although on a global scale a small lifetime change (about $-2 \%$ ) is computed (Table 6).

\section{Conclusions}

The CTM sensitivity simulations performed here show that the choice of wildfire emission inventory has a significant impact on the simulated tropospheric concentrations of both primary emitted and secondary produced species and as a result on the tropospheric lifetimes of gaseous and aerosol pollutants.

The differences introduced by the choice of biomass burning emissions are usually between -30 and $30 \%$ above and downwind of biomass burning hotspots (near the tropics, boreal forests of Russia and Canada) and can reach up to a factor of about 7 (e.g., for BC Fig. S4). These impacts maximize for primary pollutants over source areas and for secondary pollutants downwind. They are either due to the spatial and temporal differences in the emitted amounts of primary pollutants or to the resulting changes in the levels of oxidants and thus to the impact of the primary pollutants on the con- centrations of the chemically produced or destroyed tracers. The injection height of the wildfire emissions is found to affect both the tropospheric load and the lifetimes of the pollutants. Regionally, up to $30 \%$ differences are computed in the calculated tropospheric lifetimes of pollutants. The tropospheric column of OC is mostly affected by different emission injection heights with regional differences ranging from -20 to $25 \%$ and those attributed to the different emission inventories ranging from -70 to $450 \%$ (Fig. S10b).

Interestingly, isoprene, mainly emitted by vegetation, shows sensitivity to the biomass burning emissions, with increasing tropospheric concentrations (and lifetime) when fire emissions decrease mainly due to the reduction in $\mathrm{OH}$ radical concentrations. This leads to an increase of the global mean aerosol yield from isoprene, defined as the ratio of tropospheric loads of secondary aerosol from isoprene oxidation to isoprene emissions, by about $18 \%$ when biomass burning emissions are taken into account. This fractional increase shows no sensitivity to the model resolution.

Finally, comparison of model results to observations shows the limitations of current observations in evaluating the biomass burning emission inventories. Such evaluation requires densifying air quality monitoring close to and downwind of the major biomass burning sources in the tropics, over boreal regions, Alaska, southern Asia and Indonesia, where our simulations using different biomass burning emission inventories show the larger diversity.

\section{The Supplement related to this article is available online at doi:10.5194/acp-15-3543-2015-supplement.}

Acknowledgements. This work has been supported by the EUFP7 project ECLIPSE (FP7-ENV-2011-282688). N. Daskalakis acknowledges support from the EU-FP7 project PEGASOS (FP7ENV-2010-265148). The authors would like to thank the reviewers for their pertinent comments that helped improving this work.

Edited by: A. Nenes

\section{References}

Akagi, S. K., Yokelson, R. J., Wiedinmyer, C., Alvarado, M. J., Reid, J. S., Karl, T., Crounse, J. D., and Wennberg, P. O.: Emission factors for open and domestic biomass burning for use in atmospheric models, Atmos. Chem. Phys., 11, 4039-4072, doi:10.5194/acp-11-4039-2011, 2011.

Andreae, M. O. and Merlet, P.: Emission of trace gases and aerosols from biomass burning, Global Biogeochem. Сy., 15, 955-966, doi:10.1029/2000GB001382, 2001.

Beer, R., Glavich, T. A., and Rider, D. M.: Tropospheric emission spectrometer for the Earth Observing System's Aura satellite, Appl. Opt., 40, 2356-2367, doi:10.1364/AO.40.002356, 2001. 
Bond, T. C., Streets, D. G., Yarber, K. F., Nelson, S. M., Woo, J.-H., and Klimont, Z.: A technology-based global inventory of black and organic carbon emissions from combustion, J. Geophys. Res.-Atmos., 109, D14203, doi:10.1029/2003JD003697, 2004.

Carlton, A. G., Wiedinmyer, C., and Kroll, J. H.: A review of Secondary Organic Aerosol (SOA) formation from isoprene, Atmos. Chem. Phys., 9, 4987-5005, doi:10.5194/acp-9-4987-2009, 2009.

Chatfield, R. B. and Delany, A. C.: Convection links biomass burning to increased tropical ozone: However, models will tend to overpredict $\mathrm{O}_{3}$, J. Geophys. Res.-Atmos., 95, 18473-18488, doi:10.1029/JD095iD11p18473, 1990.

Colarco, P. R., Schoeberl, M. R., Doddridge, B. G., Marufu, L. T., Torres, O., and Welton, E. J.: Transport of smoke from Canadian forest fires to the surface near Washington, D.C.: Injection height, entrainment, and optical properties, J. Geophys. Res.Atmos., 109, D06203, doi:10.1029/2003JD004248, 2004.

Crounse, J. D., DeCarlo, P. F., Blake, D. R., Emmons, L. K., Campos, T. L., Apel, E. C., Clarke, A. D., Weinheimer, A. J., McCabe, D. C., Yokelson, R. J., Jimenez, J. L., and Wennberg, P. O.: Biomass burning and urban air pollution over the Central Mexican Plateau, Atmos. Chem. Phys., 9, 4929-4944, doi:10.5194/acp-9-4929-2009, 2009.

Crutzen, P. J.: An overview of atmospheric chemistry, in: Topics in Atmospheric and Interstellar Physics and Chemistry, in ERCA, vol 1, edited by: Boutron, C. F., Les Editions de Physique, France, 63-89, 1994.

Crutzen, P. J. and Andreae, M. O.: Biomass Burning in the Tropics: Impact on Atmospheric Chemistry and Biogeochemical Cycles, Science, 250, 1669-1678, doi:10.1126/science.250.4988.1669, 1990.

Dee, D. P., Uppala, S. M., Simmons, A. J., Berrisford, P., Poli, P., Kobayashi, S., Andrae, U., Balmaseda, M. A., Balsamo, G., Bauer, P., Bechtold, P., Beljaars, A. C. M., van de Berg, L., Bidlot, J., Bormann, N., Delsol, C., Dragani, R., Fuentes, M., Geer, A. J., Haimberger, L., Healy, S. B., Hersbach, H., Hólm, E. V., Isaksen, L., Kållberg, P., Köhler, M., Matricardi, M., McNally, A. P., Monge-Sanz, B. M., Morcrette, J. J., Park, B. K., Peubey, C., de Rosnay, P., Tavolato, C., Thépaut, J. N., and Vitart, F.: The ERA-Interim reanalysis: configuration and performance of the data assimilation system, Q. J. Roy. Meteor. Soc., 137, 553-597, doi:10.1002/qj.828, 2011.

Dentener, F., Kinne, S., Bond, T., Boucher, O., Cofala, J., Generoso, S., Ginoux, P., Gong, S., Hoelzemann, J. J., Ito, A., Marelli, L., Penner, J. E., Putaud, J.-P., Textor, C., Schulz, M., van der Werf, G. R., and Wilson, J.: Emissions of primary aerosol and precursor gases in the years 2000 and 1750 prescribed data-sets for AeroCom, Atmos. Chem. Phys., 6, 4321-4344, doi:10.5194/acp-64321-2006, 2006.

Dirksen, R. J., Folkert Boersma, K., de Laat, J., Stammes, P., van der Werf, G. R., Val Martin, M., and Kelder, H. M.: An aerosol boomerang: Rapid around-the-world transport of smoke from the December 2006 Australian forest fires observed from space, J. Geophys. Res.-Atmos., 114, D21201, doi:10.1029/2009JD012360, 2009.

Duan, F., Liu, X., Yu, T., and Cachier, H.: Identification and estimate of biomass burning contribution to the urban aerosol organic car- bon concentrations in Beijing, Atmos. Environ., 38, 1275-1282, doi:10.1016/j.atmosenv.2003.11.037, 2004.

Edwards, D. P., Emmons, L. K., Gille, J. C., Chu, A., Attié, J. L., Giglio, L., Wood, S. W., Haywood, J., Deeter, M. N., Massie, S. T., Ziskin, D. C., and Drummond, J. R.: Satellite-observed pollution from Southern Hemisphere biomass burning, J. Geophys. Res.-Atmos., 111, D14312, doi:10.1029/2005JD006655, 2006.

Ervens, B., Carlton, A. G., Turpin, B. J., Altieri, K. E., Kreidenweis, S. M., and Feingold, G.: Secondary organic aerosol yields from cloud-processing of isoprene oxidation products, Geophys. Res. Lett., 35, L02816, doi:10.1029/2007GL031828, 2008.

Field, R. D., van der Werf, G. R., and Shen, S. S. P.: Human amplification of drought-induced biomass burning in Indonesia since 1960, Nature Geosci., 2, 185-188, doi:10.1038/ngeo443, 2009.

Fountoukis, C. and Nenes, A.: ISORROPIA II: a computationally efficient thermodynamic equilibrium model for $\mathrm{K}^{+}-\mathrm{Ca}^{2+}$ $\mathrm{Mg}^{2+}-\mathrm{NH}_{4}^{+}-\mathrm{Na}^{+}-\mathrm{SO}_{4}^{2-}-\mathrm{NO}_{3}-\mathrm{Cl}^{-}-\mathrm{H}_{2} \mathrm{O}$ aerosols, Atmos. Chem. Phys., 7, 4639-4659, doi:10.5194/acp-7-4639-2007, 2007.

Freitas, S. R., Longo, K. M., Chatfield, R., Latham, D., Silva Dias, M. A. F., Andreae, M. O., Prins, E., Santos, J. C., Gielow, R., and Carvalho Jr., J. A.: Including the sub-grid scale plume rise of vegetation fires in low resolution atmospheric transport models, Atmos. Chem. Phys., 7, 3385-3398, doi:10.5194/acp-7-3385-2007, 2007.

Fromm, M., Alfred, J., Hoppel, K., Hornstein, J., Bevilacqua, R., Shettle, E., Servranckx, R., Li, Z., and Stocks, B.: Observations of boreal forest fire smoke in the stratosphere by POAM III, SAGE II, and lidar in 1998, Geophys. Res. Lett., 27, 1407-1410, doi:10.1029/1999GL011200, 2000.

Galanter, M., Levy, H., and Carmichael, G. R.: Impacts of biomass burning on tropospheric $\mathrm{CO}, \mathrm{NO}_{\mathrm{x}}$, and $\mathrm{O}_{3}$, J. Geophys. Res.Atmos., 105, 6633-6653, doi:10.1029/1999JD901113, 2000.

Granier, C., Bessagnet, B., Bond, T., D’Angiola, A., Denier van der Gon, H., Frost, G., Heil, A., Kaiser, J., Kinne, S., Klimont, Z., Kloster, S., Lamarque, J.-F., Liousse, C., Masui, T., Meleux, F., Mieville, A., Ohara, T., Raut, J.-C., Riahi, K., Schultz, M., Smith, S., Thompson, A., van Aardenne, J., van der Werf, G., and van Vuuren, D.: Evolution of anthropogenic and biomass burning emissions of air pollutants at global and regional scales during the 1980-2010 period, Climatic Change, 109, 163-190, doi:10.1007/s10584-011-0154-1, 2011.

Guan, H., Chatfield, R. B., Freitas, S. R., Bergstrom, R. W., and Longo, K. M.: Modeling the effect of plume-rise on the transport of carbon monoxide over Africa with NCAR CAM, Atmos. Chem. Phys., 8, 6801-6812, doi:10.5194/acp-8-6801-2008, 2008.

Guenther, A. B., Jiang, X., Heald, C. L., Sakulyanontvittaya, T., Duhl, T., Emmons, L. K., and Wang, X.: The Model of Emissions of Gases and Aerosols from Nature version 2.1 (MEGAN2.1): an extended and updated framework for modeling biogenic emissions, Geosci. Model Dev., 5, 1471-1492, doi:10.5194/gmd-51471-2012, 2012.

Hodzic, A., Vautard, R., Chepfer, H., Goloub, P., Menut, L., Chazette, P., Deuzé, J. L., Apituley, A., and Couvert, P.: Evolution of aerosol optical thickness over Europe during the August 2003 heat wave as seen from CHIMERE model simulations and POLDER data, Atmos. Chem. Phys., 6, 1853-1864, doi:10.5194/acp-6-1853-2006, 2006. 
Honrath, R. E., Owen, R. C., Martin, M. V., Reid, J. S., Lapina, K., Fialho, P., Dziobak, M. P., Kleissl, J., and Westphal, D. L.: Regional and hemispheric impacts of anthropogenic and biomass burning emissions on summertime $\mathrm{CO}$ and $\mathrm{O}_{3}$ in the North Atlantic lower free troposphere, J. Geophys. Res.-Atmos., 109, D24310, doi:10.1029/2004jd005147, 2004.

Jaffe, D. A. and Wigder, N. L.: Ozone production from wildfires: A critical review, Atmos. Environ., 51, 1-10, doi:10.1016/j.atmosenv.2011.11.063, 2012.

Jaffe, D., Bertschi, I., Jaeglé, L., Novelli, P., Reid, J. S., Tanimoto, H., Vingarzan, R., and Westphal, D. L.: Long-range transport of Siberian biomass burning emissions and impact on surface ozone in western North America, Geophys. Res. Lett., 31, L16106, doi:10.1029/2004GL020093, 2004.

Jian, Y. and Fu, T.-M.: Injection heights of springtime biomassburning plumes over peninsular Southeast Asia and their impacts on long-range pollutant transport, Atmos. Chem. Phys., 14, 3977-3989, doi:10.5194/acp-14-3977-2014, 2014.

Kaiser, J. W., Heil, A., Andreae, M. O., Benedetti, A., Chubarova, N., Jones, L., Morcrette, J.-J., Razinger, M., Schultz, M. G., Suttie, M., and van der Werf, G. R.: Biomass burning emissions estimated with a global fire assimilation system based on observed fire radiative power, Biogeosciences, 9, 527-554, doi:10.5194/bg-9-527-2012, 2012

Kanakidou, M. and Crutzen, P. J.: The photochemical source of carbon monoxide: Importance, uncertainties and feedbacks, Chemosphere - Global Change Science, 1, 91-109, doi:10.1016/S14659972(99)00022-7, 1999.

Kanakidou, M., Tsigaridis, K., Dentener, F. J., and Crutzen, P. J.: Human-activity-enhanced formation of organic aerosols by biogenic hydrocarbon oxidation, J. Geophys. Res.-Atmos., 105, 9243-9354, doi:10.1029/1999JD901148, 2000.

Kanakidou, M., Duce, R. A., Prospero, J. M., Baker, A. R., BenitezNelson, C., Dentener, F. J., Hunter, K. A., Liss, P. S., Mahowald, N., Okin, G. S., Sarin, M., Tsigaridis, K., Uematsu, M., Zamora, L. M., and Zhu, T.: Atmospheric fluxes of organic N and $\mathrm{P}$ to the global ocean, Global Biogeochem. Cy., 26, GB3026, doi:10.1029/2011GB004277, 2012.

Keywood, M., Kanakidou, M., Stohl, A., Dentener, F., Grassi, G., Meyer, C. P., Torseth, K., Edwards, D., Thompson, A. M., Lohmann, U., and Burrows, J.: Fire in the Air: Biomass Burning Impacts in a Changing Climate, Crit. Rev. Env. Sci. Tec., 43, 40-83, doi:10.1080/10643389.2011.604248, 2013.

Klimont, Z., Smith, S. J., and Cofala, J.: The last decade of global anthropogenic sulfur dioxide: 2000-2011 emissions, Environ. Res. Lett., 8, 014003, doi:10.1088/1748-9326/8/1/014003, 2013.

Lamarque, J.-F., Shindell, D. T., Josse, B., Young, P. J., Cionni, I., Eyring, V., Bergmann, D., Cameron-Smith, P., Collins, W. J., Doherty, R., Dalsoren, S., Faluvegi, G., Folberth, G., Ghan, S. J., Horowitz, L. W., Lee, Y. H., MacKenzie, I. A., Nagashima, T., Naik, V., Plummer, D., Righi, M., Rumbold, S. T., Schulz, M., Skeie, R. B., Stevenson, D. S., Strode, S., Sudo, K., Szopa, S., Voulgarakis, A., and Zeng, G.: The Atmospheric Chemistry and Climate Model Intercomparison Project (ACCMIP): overview and description of models, simulations and climate diagnostics, Geosci. Model Dev., 6, 179-206, doi:10.5194/gmd-6-179-2013, 2013.

Lavoué, D., Liousse, C., Cachier, H., Stocks, B. J., and Goldammer, J. G.: Modeling of carbonaceous particles emitted by boreal and temperate wildfires at northern latitudes, J. Geophys. Res.Atmos., 105, 26871-26890, doi:10.1029/2000JD900180, 2000.

Lelieveld, J., van Aardenne, J., Fischer, H., de Reus, M., Williams, J., and Winkler, P.: Increasing Ozone over the Atlantic Ocean, Science, 304, 1483-1487, doi:10.1126/science.1096777, 2004.

Leung, F.-Y. T., Logan, J. A., Park, R., Hyer, E., Kasischke, E., Streets, D., and Yurganov, L.: Impacts of enhanced biomass burning in the boreal forests in 1998 on tropospheric chemistry and the sensitivity of model results to the injection height of emissions, J. Geophys. Res.-Atmos., 112, D10313, doi:10.1029/2006JD008132, 2007.

Levine, J. S., Cofer, W. R., III, Cahoon, D. R., Jr., and Winstead, E. L.: Biomass Burning: A DRIVER FOR GLOBAL CHANGE, Environ. Sci. Technol., 29, 120A-125A, doi:10.1021/es00003a746, 1995.

Mutch, R. W.: Fighting Fire with Prescribed Fire: A Return to Ecosystem Health, J. Forest., 92, 31-33, 1994.

Myriokefalitakis, S., Vignati, E., Tsigaridis, K., Papadimas, C., Sciare, J., Mihalopoulos, N., Facchini, M. C., Rinaldi, M., Dentener, F. J., Ceburnis, D., Hatzianastasiou, N., O’Dowd, C. D., van Weele, M., and Kanakidou, M.: Global Modeling of the Oceanic Source of Organic Aerosols, Advances in Meteorology, 2010, 1-16, doi:10.1155/2010/939171, 2010.

Myriokefalitakis, S., Tsigaridis, K., Mihalopoulos, N., Sciare, J., Nenes, A., Kawamura, K., Segers, A., and Kanakidou, M.: Incloud oxalate formation in the global troposphere: a 3-D modeling study, Atmos. Chem. Phys., 11, 5761-5782, doi:10.5194/acp11-5761-2011, 2011.

Myriokefalitakis, S., Daskalakis, N., Fanourgakis, G. S., Voulgarakis, A., Aan de Brugh, J. M. J., Krol, M. C., and Kanakidou, M.: Pollution over the Mediterranean Basin: The Importance of Long - Range Transport for ozone and carbon monoxide, to be submitted to ACP, 2015.

Nenes, A., Pandis, S., and Pilinis, C.: ISORROPIA: A New Thermodynamic Equilibrium Model for Multiphase Multicomponent Inorganic Aerosols, Aquat. Geochem., 4, 123-152, doi:10.1023/A:1009604003981, 1998.

Palmer, P. I., Parrington, M., Lee, J. D., Lewis, A. C., Rickard, A. R., Bernath, P. F., Duck, T. J., Waugh, D. L., Tarasick, D. W., Andrews, S., Aruffo, E., Bailey, L. J., Barrett, E., Bauguitte, S. J.-B., Curry, K. R., Di Carlo, P., Chisholm, L., Dan, L., Forster, G., Franklin, J. E., Gibson, M. D., Griffin, D., Helmig, D., Hopkins, J. R., Hopper, J. T., Jenkin, M. E., Kindred, D., Kliever, J., Le Breton, M., Matthiesen, S., Maurice, M., Moller, S., Moore, D. P., Oram, D. E., O’Shea, S. J., Owen, R. C., Pagniello, C. M. L. S., Pawson, S., Percival, C. J., Pierce, J. R., Punjabi, S., Purvis, R. M., Remedios, J. J., Rotermund, K. M., Sakamoto, K. M., da Silva, A. M., Strawbridge, K. B., Strong, K., Taylor, J., Trigwell, R., Tereszchuk, K. A., Walker, K. A., Weaver, D., Whaley, C., and Young, J. C.: Quantifying the impact of BOReal forest fires on Tropospheric oxidants over the Atlantic using Aircraft and Satellites (BORTAS) experiment: design, execution and science overview, Atmos. Chem. Phys., 13, 6239-6261, doi:10.5194/acp-13-6239-2013, 2013.

Parrington, M., Palmer, P. I., Lewis, A. C., Lee, J. D., Rickard, A. R., Di Carlo, P., Taylor, J. W., Hopkins, J. R., Punjabi, S., Oram, D. E., Forster, G., Aruffo, E., Moller, S. J., Bauguitte, S. J.-B., Allan, J. D., Coe, H., and Leigh, R. J.: Ozone photochemistry in 
boreal biomass burning plumes, Atmos. Chem. Phys., 13, 73217341, doi:10.5194/acp-13-7321-2013, 2013.

Petrenko, M., Kahn, R., Chin, M., Soja, A., Kucsera, T., and Harshvardhan: The use of satellite-measured aerosol optical depth to constrain biomass burning emissions source strength in the global model GOCART, J. Geophys. Res.-Atmos., 117, D18212, doi:10.1029/2012JD017870, 2012.

Pfister, G., Hess, P. G., Emmons, L. K., Lamarque, J. F., Wiedinmyer, C., Edwards, D. P., Pétron, G., Gille, J. C., and Sachse, G. W.: Quantifying CO emissions from the 2004 Alaskan wildfires using MOPITT CO data, Geophys. Res. Lett., 32, L11809, doi:10.1029/2005GL022995, 2005.

Praplan, A. P., Barmet, P., Dommen, J., and Baltensperger, U.: Cyclobutyl methyl ketone as a model compound for pinonic acid to elucidate oxidation mechanisms, Atmos. Chem. Phys., 12, 10749-10758, doi:10.5194/acp-12-10749-2012, 2012.

Reid, J. S., Eck, T. F., Christopher, S. A., Koppmann, R., Dubovik, O., Eleuterio, D. P., Holben, B. N., Reid, E. A., and Zhang, J.: A review of biomass burning emissions part III: intensive optical properties of biomass burning particles, Atmos. Chem. Phys., 5, 827-849, doi:10.5194/acp-5-827-2005, 2005.

Rollins, A. W., Kiendler-Scharr, A., Fry, J. L., Brauers, T., Brown, S. S., Dorn, H.-P., Dubé, W. P., Fuchs, H., Mensah, A., Mentel, T. F., Rohrer, F., Tillmann, R., Wegener, R., Wooldridge, P. J., and Cohen, R. C.: Isoprene oxidation by nitrate radical: alkyl nitrate and secondary organic aerosol yields, Atmos. Chem. Phys., 9, 6685-6703, doi:10.5194/acp-9-6685-2009, 2009.

Rosenfeld, D.: TRMM observed first direct evidence of smoke from forest fires inhibiting rainfall, Geophys. Res. Lett., 26, 31053108, doi:10.1029/1999GL006066, 1999.

Simmonds, P. G., Manning, A. J., Derwent, R. G., Ciais, P., Ramonet, M., Kazan, V., and Ryall, D.: A burning question. Can recent growth rate anomalies in the greenhouse gases be attributed to large-scale biomass burning events?, Atmos. Environ., 39, 2513-2517, doi:10.1016/j.atmosenv.2005.02.018, 2005.

Sindelarova, K., Granier, C., Bouarar, I., Guenther, A., Tilmes, S., Stavrakou, T., Müller, J.-F., Kuhn, U., Stefani, P., and Knorr, W.: Global data set of biogenic VOC emissions calculated by the MEGAN model over the last 30 years, Atmos. Chem. Phys., 14, 9317-9341, doi:10.5194/acp-14-9317-2014, 2014.

Sofiev, M., Ermakova, T., and Vankevich, R.: Evaluation of the smoke-injection height from wild-land fires using remote-sensing data, Atmos. Chem. Phys., 12, 1995-2006, doi:10.5194/acp-12-1995-2012, 2012.

Sofiev, M., Vankevich, R., Ermakova, T., and Hakkarainen, J.: Global mapping of maximum emission heights and resulting vertical profiles of wildfire emissions, Atmos. Chem. Phys., 13, 7039-7052, doi:10.5194/acp-13-7039-2013, 2013.

Tsigaridis, K. and Kanakidou, M.: Global modelling of secondary organic aerosol in the troposphere: a sensitivity analysis, Atmos. Chem. Phys., 3, 1849-1869, doi:10.5194/acp-3-1849-2003, 2003.

Tsigaridis, K. and Kanakidou, M.: Secondary organic aerosol importance in the future atmosphere, Atmos. Environ., 41, 46824692, doi:10.1016/j.atmosenv.2007.03.045, 2007.

Tsigaridis, K., Krol, M., Dentener, F. J., Balkanski, Y., Lathière, J., Metzger, S., Hauglustaine, D. A., and Kanakidou, M.: Change in global aerosol composition since preindustrial times, At- mos. Chem. Phys., 6, 5143-5162, doi:10.5194/acp-6-5143-2006, 2006.

Tsigaridis, K., Daskalakis, N., Kanakidou, M., Adams, P. J., Artaxo, P., Bahadur, R., Balkanski, Y., Bauer, S. E., Bellouin, N., Benedetti, A., Bergman, T., Berntsen, T. K., Beukes, J. P., Bian, H., Carslaw, K. S., Chin, M., Curci, G., Diehl, T., Easter, R. C., Ghan, S. J., Gong, S. L., Hodzic, A., Hoyle, C. R., Iversen, T., Jathar, S., Jimenez, J. L., Kaiser, J. W., Kirkevåg, A., Koch, D., Kokkola, H., Lee, Y. H, Lin, G., Liu, X., Luo, G., Ma, X., Mann, G. W., Mihalopoulos, N., Morcrette, J.-J., Müller, J.-F., Myhre, G., Myriokefalitakis, S., Ng, N. L., O’Donnell, D., Penner, J. E., Pozzoli, L., Pringle, K. J., Russell, L. M., Schulz, M., Sciare, J., Seland, Ø., Shindell, D. T., Sillman, S., Skeie, R. B., Spracklen, D., Stavrakou, T., Steenrod, S. D., Takemura, T., Tiitta, P., Tilmes, S., Tost, H., van Noije, T., van Zyl, P. G., von Salzen, K., Yu, F., Wang, Z., Wang, Z., Zaveri, R. A., Zhang, H., Zhang, K., Zhang, Q., and Zhang, X.: The AeroCom evaluation and intercomparison of organic aerosol in global models, Atmos. Chem. Phys., 14, 10845-10895, doi:10.5194/acp-1410845-2014, 2014.

Val Martin, M., Logan, J. A., Kahn, R. A., Leung, F.-Y., Nelson, D. L., and Diner, D. J.: Smoke injection heights from fires in North America: analysis of 5 years of satellite observations, Atmos. Chem. Phys., 10, 1491-1510, doi:10.5194/acp-10-14912010, 2010.

Val Martin, M., Kahn, R. A., Logan, J. A., Paugam, R., Wooster, M., and Ichoku, C.: Space-based observational constraints for 1D fire smoke plume-rise models, J. Geophys. Res.-Atmos., 117, D22204, doi:10.1029/2012jd018370, 2012.

van der Werf, G. R., Randerson, J. T., Giglio, L., Collatz, G. J., Kasibhatla, P. S., and Arellano Jr., A. F.: Interannual variability in global biomass burning emissions from 1997 to 2004, Atmos. Chem. Phys., 6, 3423-3441, doi:10.5194/acp-6-3423-2006, 2006.

van der Werf, G. R., Randerson, J. T., Giglio, L., Collatz, G. J., Mu, M., Kasibhatla, P. S., Morton, D. C., DeFries, R. S., Jin, Y., and van Leeuwen, T. T.: Global fire emissions and the contribution of deforestation, savanna, forest, agricultural, and peat fires (19972009), Atmos. Chem. Phys., 10, 11707-11735, doi:10.5194/acp10-11707-2010, 2010.

Vignati, E., Facchini, M. C., Rinaldi, M., Scannell, C., Ceburnis, D., Sciare, J., Kanakidou, M., Myriokefalitakis, S., Dentener, F., and O'Dowd, C. D.: Global scale emission and distribution of seaspray aerosol: Sea-salt and organic enrichment, Atmos. Environ., 44, 670-677, doi:10.1016/j.atmosenv.2009.11.013, 2010.

Voulgarakis, A., Telford, P. J., Aghedo, A. M., Braesicke, P., Faluvegi, G., Abraham, N. L., Bowman, K. W., Pyle, J. A., and Shindell, D. T.: Global multi-year $\mathrm{O}_{3}-\mathrm{CO}$ correlation patterns from models and TES satellite observations, Atmos. Chem. Phys., 11, 5819-5838, doi:10.5194/acp-11-5819-2011, 2011.

Wiedinmyer, C., Akagi, S. K., Yokelson, R. J., Emmons, L. K., AlSaadi, J. A., Orlando, J. J., and Soja, A. J.: The Fire INventory from NCAR (FINN): a high resolution global model to estimate the emissions from open burning, Geosci. Model Dev., 4, 625641, doi:10.5194/gmd-4-625-2011, 2011.

Williams, J. E., Weele, M. v., Velthoven, P. F. J. v., Scheele, M. P., Liousse, C., and Werf, G. R. v. d.: The Impact of Uncertainties in African Biomass Burning Emission Estimates on Modeling Global Air Quality, Long Range Transport and 
Tropospheric Chemical Lifetimes, Atmosphere, 3, 132-163, doi:10.3390/atmos3010132, 2012.
Ziemke, J. R., Chandra, S., Duncan, B. N., Schoeberl, M. R., Torres, O., Damon, M. R., and Bhartia, P. K.: Recent biomass burning in the tropics and related changes in tropospheric ozone, Geophys. Res. Lett., 36, L15819, doi:10.1029/2009GL039303, 2009. 